\title{
Biogeochemical cycling and phyto- and bacterioplankton communities in a large and shallow tropical lagoon (Términos Lagoon, Mexico) under 2009-2010 El Niño Modoki drought conditions
}

\author{
Pascal Conan ${ }^{1}$, Mireille Pujo-Pay ${ }^{1}$, Marina Agab ${ }^{1}$, Laura Calva-Benítez ${ }^{2}$, Sandrine Chifflet ${ }^{3}$, Pascal Douillet ${ }^{3}$, \\ Claire Dussud $^{1}$, Renaud Fichez ${ }^{3}$, Christian Grenz ${ }^{3}$, Francisco Gutierrez Mendieta ${ }^{2}$, Montserrat Origel-Moreno ${ }^{2,3}$, \\ Arturo Rodríguez-Blanco ${ }^{1}$, Caroline Sauret ${ }^{1}$, Tatiana Severin ${ }^{1}$, Marc Tedetti ${ }^{3}$, Rocío Torres Alvarado ${ }^{2}$, and \\ Jean-François Ghiglione ${ }^{1}$ \\ ${ }^{1}$ Sorbonne Universités, UPMC Univ Paris 06, CNRS, Laboratoire d'Océanographie Microbienne (LOMIC), \\ Observatoire Océanologique, 66650, Banyuls/mer, France \\ ${ }^{2}$ Universidad Autónoma Metropolitana, Departamento de Hidrobiología, México D.F., Mexico \\ ${ }^{3}$ Aix-Marseille Université, CNRS-INSU, Université de Toulon, IRD, Mediterranean Institute of Oceanography (MIO) \\ UM 110, 13288, Marseille, France
}

Correspondence to: Pascal Conan (pascal.conan@obs-banyuls.fr)

Received: 8 July 2016 - Discussion started: 11 August 2016

Revised: 6 January 2017 - Accepted: 25 January 2017 - Published: 2 March 2017

\begin{abstract}
The 2009-2010 period was marked by an episode of intense drought known as the El Niño Modoki event. Sampling of the Términos Lagoon (Mexico) was carried out in November 2009 in order to understand the influence of these particular environmental conditions on organic matter fluxes within the lagoon's pelagic ecosystem and, more specifically, on the relationship between phyto- and bacterioplankton communities. The measurements presented here concern biogeochemical parameters (nutrients, dissolved and particulate organic matter [POM], and dissolved polycyclic aromatic hydrocarbons [PAHs]), phytoplankton (biomass and photosynthesis), and bacteria (diversity and abundance, including PAH degradation bacteria and ectoenzymatic activities). During the studied period, the water column of the Términos Lagoon functioned globally as a sink and, more precisely, as a "nitrogen assimilator". This was due to the high production of particulate and dissolved organic matter (DOM), even though exportation of autochthonous matter to the Gulf of Mexico was weak. We found that "bottom-up" control accounted for a large portion of the variability of phytoplankton productivity. Nitrogen and phosphorus stoichiometry mostly accounted for the heterogeneity in phytoplankton and free-living prokaryote distribution in the lagoon. In
\end{abstract}

the eastern part, we found a clear decoupling between areas enriched in dissolved inorganic nitrogen near the Puerto Real coastal inlet and areas enriched in phosphate $\left(\mathrm{PO}_{4}\right)$ near the Candelaria estuary. Such a decoupling limited the potential for primary production, resulting in an accumulation of dissolved organic carbon and nitrogen (DOC and DON, respectively) near the river mouths. In the western part of the lagoon, maximal phytoplankton development resulted from bacterial activity transforming particulate organic phosphorus (PP) and dissolved organic phosphorus (DOP) to available $\mathrm{PO}_{4}$ and the coupling between Palizada River inputs of nitrate $\left(\mathrm{NO}_{3}\right)$ and $\mathrm{PP}$. The Chumpan River contributed only marginally to $\mathrm{PO}_{4}$ inputs due to its very low contribution to overall river inputs. The highest dissolved total PAH concentrations were measured in the El Carmen Inlet, suggesting that the anthropogenic pollution of the zone is probably related to the oil-platform exploitation activities in the shallow waters of the southern of the Gulf of Mexico. We also found that a complex array of biogeochemical and phytoplanktonic parameters were the driving force behind the geographical distribution of bacterial community structure and activities. Finally, we showed that nutrients brought by the Palizada River supported an abundant bacterial community of PAH 
degraders, which are of significance in this important oilproduction zone.

\section{Introduction}

Coastal lagoons are complex environments, combining features of shallow inland waterbodies wholly or partly sealed off from the adjacent coastal oceans. They are influenced by tides, river inputs, the precipitation versus evaporation balance, and the surface heat balance. Interactions between freshwater and marine sources generate strong gradients of salinity, light, and nutrient availability (Hauenstein and Ramírez, 1986). Biological diversity is generally high in these environments (Milessi et al., 2010). Located in the southern Gulf of Mexico near Campeche Sound, the Términos Lagoon is one of the largest tropical coastal lagoons worldwide, and its recognized environmental importance and protected status are potentially threatened by petroleumrelated industrial activities inshore and offshore (García-Ríos et al., 2013). A first tentative budget of salt and nutrients concluded that the Términos Lagoon was slightly autotrophic on a yearly basis (David, 1999), but this assessment was clearly based on scarce environmental data. Chlorophyll $a$ (Chl $a$ ) concentration and phytoplankton net production have been reported to range from 1 to $17 \mu \mathrm{g} \mathrm{L}^{-1}$ and from 20 to $300 \mathrm{gC} \mathrm{m}^{-2} \mathrm{yr}^{-1}$ respectively (Day et al., 1982), suggesting a potential shift from oligotrophic to eutrophic conditions.

In aquatic ecosystems, bacteria utilize a large fraction (up to $90 \%$ ) of the primary production, since algal carbon exudates can be the principal source for bacterial production (Cole et al., 1988; Conan et al., 1999). Besides the utilization of a considerable part of the available organic matter, bacterioplankton communities also absorb inorganic nutrients, thus competing with phytoplankton communities (Conan et al., 2007; Hobbie, 1988). The bulk of the organic matter is a highly heterogeneous matrix which is primarily composed of complex and refractory substrates (Hoppe et al., 2002), but which also contains labile substrates such as proteins or peptides, oligosaccharides, and fatty acids. Extracellular enzymes are thus essential to aquatic microorganisms as they allow for the partitioning of complex organic substrates, including high molecular weight compounds which cannot pass through the cell membrane (Arnosti and Steen, 2013). As a function of genetic diversity, the capacity to produce extracellular enzymes is differently distributed in the bacterial community, directly impacting the range of substrates metabolized (Zimmerman et al., 2013). This phenomenon has global-scale implications since several meta-analyses have clearly evidenced differences in the metabolic capacities of microorganisms from temperate, tropical, or high latitude waters (Amado et al., 2013; Arnosti et al., 2011). At a local scale, alteration of the evaporation-precipitation balance due to climate change can be challenging, especially in the case of a coastal lagoon, as it is well known that changes in salinity may alter bacterial diversity and activity (PedrósAlió et al., 2000). Local anthropogenic inputs of organic pollutants such as polycyclic aromatic hydrocarbons (PAHs) may also affect bacterial diversity and activity (Aguayo et al., 2014; Jiménez et al., 2011; Rodríguez-Blanco et al., 2010). Indeed, PAHs, which can comprise as much as $25-35 \%$ of total hydrocarbon content in crude oils (Head et al., 2006), are among the most abundant and ubiquitous pollutants in the coastal environment (González-Gaya et al., 2016). These compounds are recognized by the European and US environmental agencies as priority pollutants for the aquatic medium due to their toxicity, persistence, and ability to accumulate in the biota (Kennish, 1992). Hence, the presence of PAHs in the marine environment may induce an increase in the indigenous populations of marine bacteria that can break down and utilize these chemicals as a carbon source, the so-called "PAH-degrading bacteria" or "PAH degraders". These bacteria are generally strongly selected in oil-impacted ecosystems, where they may account for 70 to $90 \%$ of the total bacterial community (Gutierrez et al., 2014; Head et al., 2006).

Despite their importance, few studies have considered the bacterial communities of tropical inland aquatic ecosystems (Roland et al., 2010) or coastal lagoons (Abreu et al., 1992; Hsieh et al., 2012; MacCord et al., 2013; They et al., 2013) and almost none have dealt with tropical coastal lagoons (Scofield et al., 2015). Among the existing studies, very few have been conducted on bacterial communities and most of them have been based on culture-dependent methods (Lizárraga-Partida et al., 1987, 1986). However, cultivable bacteria represent a very small fraction of the total present bacteria ( $<0.1 \%$; Ferguson et al., 1984), and cultureindependent methods are needed to more accurately assess the diversity and activity of whole bacterial communities in such a vast and understudied system. Additionally, the Términos Lagoon is potentially impacted by PAHs which may come from a variety of sources which all carry various urban and industrial wastes (fuel combustion and traffic exhaust emissions) including sea-based activities (ballast water discharge, drilling, and spills from ships, platforms and pipelines), rivers, surface runoffs, and the atmosphere. Nevertheless, to our knowledge, little is known about the PAH content in this ecosystem. Even though Noreña-Barroso et al. (1999) reported on PAH concentrations in the American oyster Crassostrea virginica and Osten-Von Rendon et al. (2007) studied PAH concentrations in surface sediments, no data are currently available concerning dissolved PAH concentrations in the surface waters of the Términos Lagoon.

Our study aims to evaluate the link between (i) biogeochemical (nutrients, dissolved and particulate organic matter $[\mathrm{POM}]$ ), (ii) phytoplanktonic (biomass and photosynthetic activity), and (iii) free-living prokaryote (diversity, including PAH-degrading bacteria, and ectoenzymatic activities) parameters in the water column of the Términos Lagoon (Mexico) after a sustained period of minimum river discharge rel- 


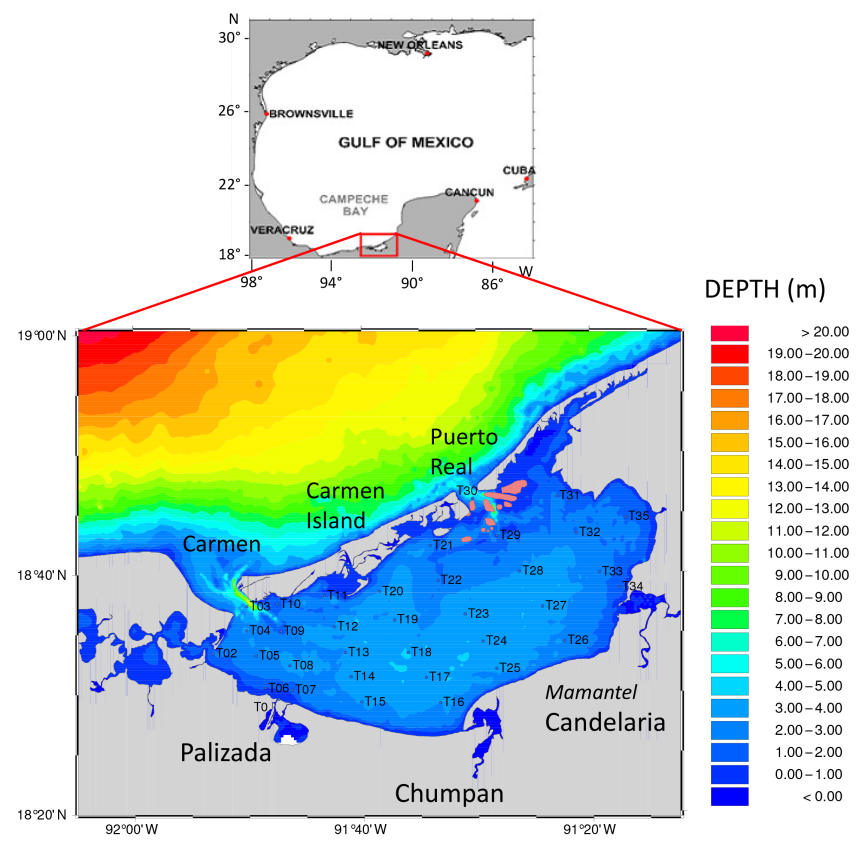

Figure 1. Study site location and distribution of the 35 sampled stations in the lagoon.

ative to the 2009-2010 El Niño Modoki episode. After having identified the main sources of nutrients in the lagoon (focused on nitrogen and phosphorus), we propose a geographical organization of the ecosystem to explain the distribution of the microbial pelagic communities across the lagoon.

\section{Materials and methods}

\subsection{Study site and sampling}

The Términos Lagoon is a large $\left(1936 \mathrm{~km}^{2}\right.$, volume $4.65 \mathrm{~km}^{3}$ ) and shallow (average depth $2.4 \mathrm{~m}$ ) coastal lagoon located in the Mexican state of Campeche (Fig. 1), $18^{\circ} 20^{\prime}$ to $19^{\circ} 00^{\prime} \mathrm{N}$ and $91^{\circ} 10^{\prime}$ to $92^{\circ} 00^{\prime} \mathrm{W}$. Temperature shows low seasonal variation $\left(27\right.$ to $\left.33^{\circ} \mathrm{C}\right)$, but salinity oscillates from brackish to marine waters due to high variability in river runoffs (Fichez et al., 2016; Gullian-Klanian et al., 2008). River discharge, precipitation, and groundwater seepage account for $95.44,4.53$ and $0.03 \%$, respectively. The Chumpan, Candelaria-Mamantel (hereafter Candelaria), and Palizada Estuaries account for 5, 19, and $76 \%$, respectively, of the freshwater delivered yearly $\left(\sim 12 \times 10^{9} \mathrm{~m}^{3} \mathrm{yr}^{-1}\right.$; i.e. about 2.6 times the lagoon volume) to the lagoon (Fichez et al., 2016). The lagoon is connected to the coastal sea by two inlets: El Carmen on the northwestern side (4 km long) and Puerto Real on the northeastern side (3.3 km in length). About half of the water volume is renewed every 9 days, mostly as a result of tidal exchange. The tide is mainly diurnal, with a mean range of $0.3 \mathrm{~m}$. (David and Kjerfve, 1998). Recent results on tidal current modeling (Contreras Ruiz Es- parza et al., 2014) reveal both a dynamic inshore current entering the lagoon through the El Carmen Inlet, flowing through the southern half of the lagoon and exiting through Puerto Real, and a much slower inverse water current flooding the northern central part of the lagoon. This tidally induced hydrodynamic trend generates a counterclockwise circulation gyre located in the center of the lagoon, on the leeward side of Carmen Island.

Samples were collected at a $0.2 \mathrm{~m}$ depth at 35 stations distributed over the whole lagoon (Fig. 1) from 21 to the 27 October 2009. In 2009, a yearly cumulative discharge of $4.83 \pm 1.71 \times 10^{9} \mathrm{~m}^{3}$ broke a historical deficit record over the 1992-2011 period for the Palizada River (average yearly cumulative discharge of $7.19 \pm 4.22 \times 10^{9} \mathrm{~m}^{3} \mathrm{yr}^{-1}$ ) (Fichez et al., 2017). That exceptional drought period impacted the entire formerly Mesoamerican region during the 2009-2010 El Niño Modoki episode. This resulted in a positive salinity anomaly in the Términos Lagoon that developed most strongly during the post-wet season period (Fichez et al., 2016) at the time of our sampling.

A vertical profile of temperature, salinity, and fluorescence was carried out at each of the 35 stations using a Sea-Bird CTD probe (SBE 19) with a precision of $0.01{ }^{\circ} \mathrm{C}$ for temperature and 0.001 for salinity. Once the profile was completed, water was sampled using a $5 \mathrm{~L}$ Niskin bottle maintained horizontally at $0.2 \mathrm{~m}$ below the surface.

\subsection{Nutrients and dissolved organic matter}

As soon as the Niskin sampler was retrieved on board, a previously acid-washed $40 \mathrm{~mL} \mathrm{Schott}{ }^{\circledR}$ glass vial was rinsed with sampled water, filled, immediately injected with the fluorometric detection reagent for ammonia determination (as described in Holmes et al., 1999), sealed, and stored in the dark for later analysis in the laboratory. Following this, two $30 \mathrm{~mL}$ and one $150 \mathrm{~mL}$ plastic acid-washed vials were then rinsed with sampled water, filled, and stored in a specifically dedicated and refrigerated ice cooler, to be later deep-frozen in the laboratory while awaiting analysis of dissolved inorganic and organic nutrients, as follows:

Nitrate $\left(\mathrm{NO}_{3} \pm 0.02 \mu \mathrm{M}\right)$, nitrite $\left(\mathrm{NO}_{2} \pm 0.01 \mu \mathrm{M}\right)$, phosphate $\left(\mathrm{PO}_{4} \pm 0.01 \mu \mathrm{M}\right)$, and silicate $\left(\mathrm{Si}(\mathrm{OH})_{4} \pm 0.05 \mu \mathrm{M}\right)$ concentrations were measured on a continuous flow Technicon ${ }^{\circledR}$ AutoAnalyzer II (Aminot and Kérouel, 2007), as previously described in Severin et al. (2014). Ammonium $\left(\mathrm{NH}_{4} \pm 10 \mathrm{nM}\right)$ was detected at nanomolar concentrations by fluorometric detection (Holmes et al., 1999) on a Turner Designs Trilogy fluorometer.

Samples for dissolved organic matter (DOM) were filtered through two precombusted $\left(24 \mathrm{~h}, 450^{\circ} \mathrm{C}\right)$ glass fiber filters (Whatman GF/F, $25 \mathrm{~mm}$ ). A total of $20 \mathrm{~mL}$ of dissolved organic carbon (DOC) was collected in precombusted glass tubes, acidified with orthophosphoric acid $\left(\mathrm{H}_{3} \mathrm{PO}_{4}\right)$, and analyzed by high temperature catalytic oxidation (HTCO) (Cauwet, 1999) on a Shimadzu TOCV analyzer. Typical ana- 
lytical precision is $\pm 0.1-0.5$ (SD) or $0.2-1 \%$ (CV). A total of $20 \mathrm{~mL}$ of dissolved organic nitrogen (DON) and phosphorus (DOP) was collected in Teflon vials and analyzed by Persulfate wet oxidation following Pujo-Pay and Raimbault (1994) and Pujo-Pay et al. (1997).

\subsection{Particulate organic matter, chlorophyll, and phaeopigment}

A $4 \mathrm{~L}$ acid-washed plastic container was also used for subsampling from the Niskin bottle. This container was rinsed with sampled water, filled, and stored in a dedicated ice cooler while awaiting filtration in the laboratory as follows: $250 \mathrm{~mL}$ of seawater was filtered through a precombusted $\left(24 \mathrm{~h}, 450{ }^{\circ} \mathrm{C}\right) \mathrm{Whatman}{ }^{\circledR} \mathrm{GF} / \mathrm{F}$ glass filters $(25 \mathrm{~mm})$, placed into a Teflon vial, and oxidized for particulate organic nitrogen (PON) and phosphorus (PP) measurements (according to Pujo-Pay and Raimbault, 1994). Approximately $1 \mathrm{~L}$ was filtered on precombusted $\left(24 \mathrm{~h}, 450^{\circ} \mathrm{C}\right)$ glass fiber filters (Whatman GF/F, $25 \mathrm{~mm}$ ) for particulate organic carbon (POC) and PON measurements. Filters were oven dried at $50^{\circ} \mathrm{C}$ and stored in washed glass vials in a desiccator until analysis using a Perkin Elmer $2400 \mathrm{CHN}$ elemental analyzer following the cruise.

For chlorophyll, $250 \mathrm{~mL}$ samples were filtered using $25 \mathrm{~mm}$ diameter Whatman ${ }^{\circledR} \mathrm{GF} / \mathrm{F}$ filters and immediately stored in liquid nitrogen. $\mathrm{Chl}$ and phaeopigment (Phaeo) were later extracted from the filters with $100 \%$ methanol (Marker, 1972). Concentrations were determined by using the fluorometric technique (Lorenzen, 1966) on a Turner Design Trilogy fluorometer.

\subsection{Photosynthetic parameters}

Photosynthetic-irradiance parameters $\left(\alpha, P_{\mathrm{m}}^{b}\right.$ and $\left.I_{k}\right)$ were measured using the radioactive ${ }^{14} \mathrm{C}$ tracer technique (Fitzwater et al., 1982) in a specially designed homemade incubator. The $10 \times 60 \mathrm{~mL} \mathrm{Nunc}{ }^{\circledR}$ culture vials were carefully filled and inoculated with $\mathrm{Na}_{2} \mathrm{H}^{14} \mathrm{CO}_{3}$ (final activity of $\sim 0.2 \mu \mathrm{Ci} \mathrm{mL}^{-1}$ ), incubated for $45 \mathrm{~min}$ in a 10 light level irradiance gradient (from 0 to $1327 \mathrm{~W} \mathrm{~m}^{-2}$ ) before being filtered on Whatman GF/F $25 \mathrm{~mm}$ filters, rinsed with $10 \% \mathrm{HCl}$, dried at $45^{\circ} \mathrm{C}$ for $12 \mathrm{~h}$, and placed into scintillation vials. A total of $10 \mathrm{~mL}$ of a liquid scintillation cocktail (Ultima Gold uLLT) was added to the set of scintillation vials $6 \mathrm{~h}$ before processing in a Beckman Scintillation Counter. The photosynthetic parameters were determined by fitting each obtained curve to the "hyperbolic tangent model without photoinhibition" proposed by Jassby and Platt (1976).

\subsection{Measurements of dissolved total PAH concentrations}

Dissolved total PAH concentrations were determined by using the EnviroFlu-HC submersible UV fluorometer (TriOS Optical Sensors, Germany), a commercially available instrument dedicated to the in situ and real-time quantification of PAHs in water. The sensor was calibrated in the laboratory before the cruises following Tedetti et al. (2010) and Sauret et al. (2016). In this work, the mean dissolved total PAH concentrations derived from the sensor are given in $\mathrm{n} \mathrm{L}^{-1}$ with a mean coefficient of variation of $10 \%$.

\subsection{Abundance of prokaryotes}

Free-living prokaryotes were determined by flow cytometry (Mével et al., 2008). Two-milliliter seawater samples were fixed with $2 \%$ formaldehyde for $1 \mathrm{~h}$ at $4{ }^{\circ} \mathrm{C}$. A $1 \mathrm{~mL}$ subsample was incubated with SYBR Green I (Sigma Aldrich, final conc. $0.05 \%[v / v]$ of the commercial solution) for $15 \mathrm{~min}$ at $20^{\circ} \mathrm{C}$ in the dark and analyzed with a FACSCalibur flow cytometer (Becton Dickinson, San Jose, CA) equipped with an air-cooled argon laser ( $488 \mathrm{nM}, 15 \mathrm{~mW})$. Data acquisition and analysis were done with Cell-Quest software (Becton Dickinson). The discrimination of the heterotrophs was undertaken using SYBR Green I to induce a green fluorescence and enable the separation of the prokaryotes using the SSC (side scatter) diffraction parameter.

\subsection{Total and metabolically active bacterial community structure}

Nucleic acids were extracted on $0.2 \mu \mathrm{m}$-pore-size filters $(47 \mathrm{~mm}, \mathrm{PC}$, Nucleopore) by the filtration of $1 \mathrm{~L}$ of prefiltered $(3 \mu \mathrm{m})$ water. Co-extraction of DNA and RNA was performed after chemical cell lysis (Ghiglione et al., 1999) with the Qiagen AllPrep DNA/RNA extraction kit using the manufacturer's instructions. DNA and cDNA (by murine leukemia virus, M-MLV, reverse transcription of $16 \mathrm{~S}$ rRNA, Promega) were used as a template for PCR amplification of the variable V3 region of the 16S rRNA gene (Escherichia coli gene positions 329-533; Brosius et al., 1981). The primer w34 was fluorescently labeled at the 5'-end position with phosphoramidite (TET, Applied Biosystems). A CESSCP (capillary electrophoresis single-strand conformation polymorphism) analysis was performed using the $310 \mathrm{Ge}-$ netic Analyzer and GeneScan Analysis Software (Applied Biosystems) as previously described by Ortega-Retuerta et al., 2012.

\subsection{Extracellular enzymatic activities}

Aminopeptidase, $\beta$-glucosidase, and lipase were measured using a VICTOR3 spectrofluorometer (Perkin Elmer) after incubations of $2 \mathrm{~h}$ at in situ temperature with L-leucine7amido-4-methyl coumarin (LL, $5 \mu \mathrm{M}$ final), MUF- $\beta$-D- 
glucoside ( $\beta$-Glc, $0.25 \mu \mathrm{M}$ final), or MUF-palmitate (Lip, $0.25 \mu \mathrm{M}$ final). These saturated concentrations and optimized time incubations were determined prior to the extracellular enzymatic activities measurement as previously described by Van Wambeke et al., 2009.

\subsection{Quantification of PAH-degrading bacteria by the most probable number method}

The quantification of PAH-degrading bacteria was performed using the most probable number (MPN) method. A total of $100 \mu \mathrm{L}$ of each sample was introduced in triplicate into a 48well microplate with $900 \mu \mathrm{L}$ of sterile minimum medium, as previously described (Rodríguez-Blanco et al., 2010; Sauret et al., 2016). A mixture of six PAHs from two to five rings (naphthalene, fluorene, phenanthrene, fluoranthene, pyrene, and benzo[a]pyrene) prepared in dichloromethane in equimolar concentration was introduced into each well at a final concentration of $10 \mu \mathrm{g} \mathrm{mL}^{-1}$ as previously described by Sauret et al. (2016). This corresponds to a very high concentration of PAH in nature, i.e. 50 times higher than the values found in the Leghorn harbor (Cincinelli et al., 2001). After two weeks of incubation, the change from blue to pink - indicating oxidation of the resazurin contained in the medium - was checked. Based on the flow cytometry quantification of the abundance of bacteria at the beginning of the incubation (see Sect. 2.6) and taking into account the dilution factors where we visually observed color changes after two weeks, the traditional MPN table gave the most probable number of bacteria able to degrade the mixture of six PAHs (Alexander, 1982).

\subsection{Statistical analysis}

The comparative analysis of 16S rDNA- or 16S rRNA-based CE-SSCP fingerprints was carried out with the PRIMER 6 software (PRIMER-E, Ltd., UK) using Bray-Curtis similarities. We used the similarity profile test (SIMPROF) (PRIMER 6) to check whether a specific sub-cluster can be recreated by randomly permuting the entry ribotypes and samples when using hierarchical agglomerative clustering. The significant branch (SIMPROF, $p<0.05$ ) was used as a prerequisite for defining bacterial clusters, and clusters were reported using non-metric multidimensional scaling (NMDS) representation.

Canonical correspondence analysis (CCA) was used to investigate the variations in the CE-SSCP profiles under the constraint of our set of environmental variables using CANOCO software (version 5.0) as previously described in Berdjeb et al. (2011). Significant variables (i.e. variables that significantly explained changes in $16 \mathrm{~S}$ rDNA- and $16 \mathrm{~S}$ rRNA-based fingerprints) in our dataset were chosen using a forward-selection procedure. Explanatory variables were added until further addition of variables failed to contribute significantly $(p<0.05)$ to a substantial improvement in the model's explanatory power. Environmental parameters were previously transformed according to their pairwise distributions, and Spearman's rank pairwise correlations between the transformed environmental variables were used to determine their significance with StatEL v2.7.

\subsection{Results}

\subsection{Distribution of physical parameters}

In the studied period, the Términos Lagoon was characterized by a northwest-southeast positive temperature gradient from $>30$ to about $27^{\circ} \mathrm{C}$ (Fig. 2a). Salinity was maximal at the Puerto Real Inlet (37.50) and along the southern limits of Carmen Island, intermediate at Candelaria and Chumpan River mouths, and minimal (21.57) near the Palizada River (Fig. 2b).

\subsection{Distribution of biogeochemical parameters}

Nitrate and ammonium concentrations (Fig. 2c and d) were at maximum near the Palizada river outlet (16.6 and $0.3 \mu \mathrm{M}$, respectively) and the Puerto Real Inlet $\left(2.5 \mu \mathrm{M}\right.$ in $\mathrm{NO}_{3}$ and the highest $\mathrm{NH}_{4}$ concentration of $1 \mu \mathrm{M}$ ). In the rest of the lagoon, $\mathrm{NO}_{3}$ concentrations were quite low and homogeneous (close to the detection limit of $0.01 \mu \mathrm{M}$ ). $\mathrm{NH}_{4}$ concentrations were more variable, with minimum values on the northern side of the lagoon and concentrations in the 0.1 to $0.3 \mu \mathrm{M}$ range on the southern inshore side.

The distribution pattern for $\mathrm{PO}_{4}$ (Fig. 2e) differed significantly from $\mathrm{N}$-nutrients. Minimum concentrations $(<0.05 \mu \mathrm{M})$ were measured in the western part of the lagoon under the influence of the Palizada River, indicating very low $\mathrm{PO}_{4}$ inputs from that river as opposed to nitrogen-nutrients. $\mathrm{PO}_{4}$ concentrations were also low $(<0.10 \mu \mathrm{M})$ in the center of the lagoon. The highest $\mathrm{PO}_{4}$ concentration was measured in the vicinity of the Chumpan River $(0.17 \mu \mathrm{M})$ whereas significant inputs in the eastern part came from the Candelaria River $(0.13 \mu \mathrm{M})$ and the Puerto Real Inlet $(0.12 \mu \mathrm{M})$.

The distributions of dissolved organic carbon (DOC; Fig. 2f), nitrogen (DON; Fig. 2g), and phosphorus (DOP; Fig. 2h) concentrations followed a pattern comparable to that of $\mathrm{PO}_{4}$. The higher concentrations of DOC, DON, and DOP were measured in the southeastern part of the lagoon. However, the maximal DOC and DON concentrations ( $>400$ and $20 \mu \mathrm{M}$, respectively) were measured near the Candelaria River outlet, whereas the maximal DOP concentrations were observed off of the Chumpan River $(>1 \mu \mathrm{M})$. The lowest concentrations $<200,5$, and $0.1 \mu \mathrm{M}$ of DOC, DON, and DOP were measured in the vicinity of the Palizada River outlet. These relatively weak concentrations even spread along the northern shore of Carmen Island for DOC. Significant Spearman's rank correlations $(n=35, p<0.05)$ were found between DON and DOC $(\rho=0.64)$, DOP $(\rho=0.64)$, and temperature $(\rho=-0.32)$. 

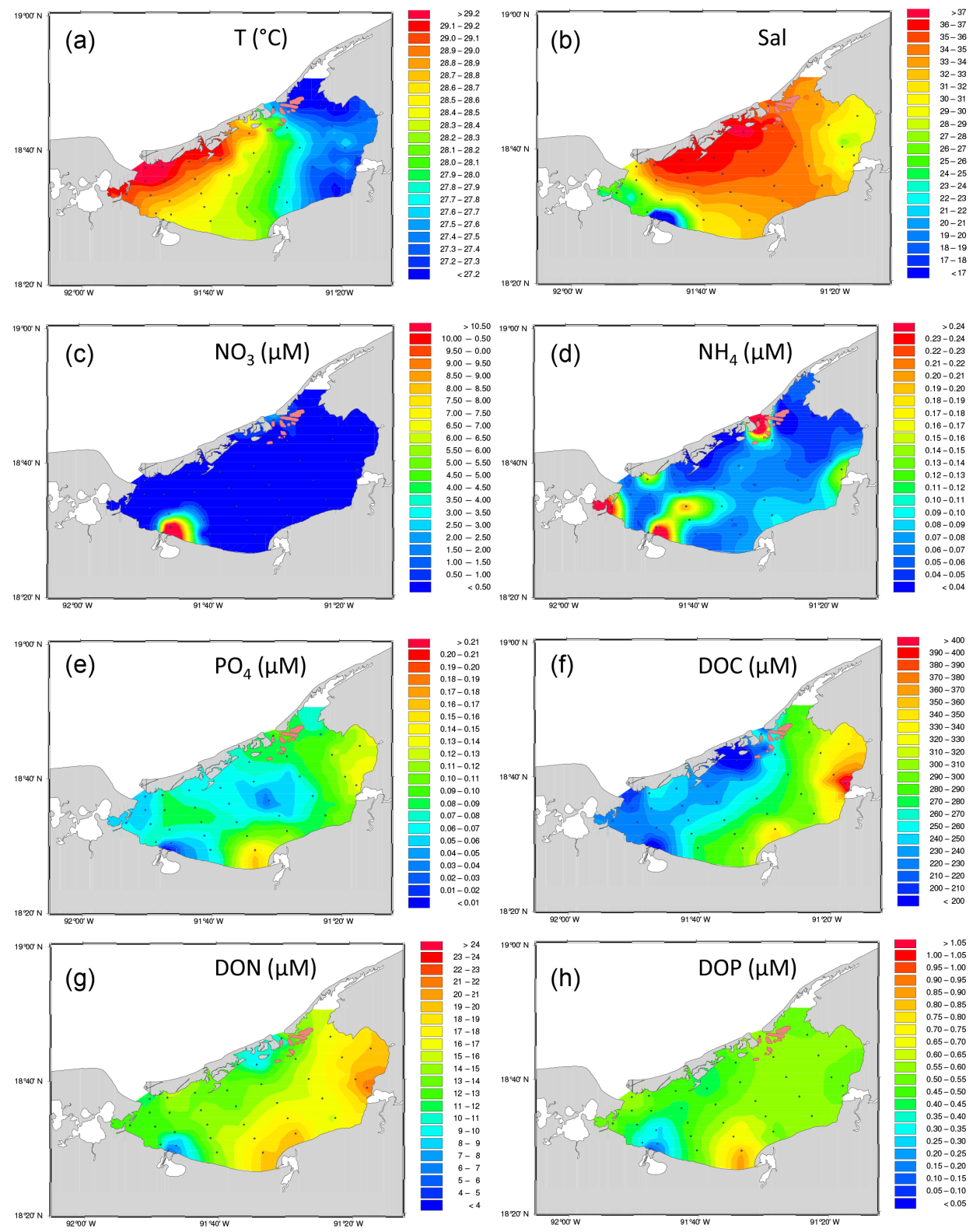

Figure 2. Mapped distribution of the physico-chemical parameters measured in the Términos Lagoon in October 2009 for (a) temperature $\left({ }^{\circ} \mathrm{C}\right)$; (b) salinity; (c) nitrate concentrations $\left(\mathrm{NO}_{3}\right.$ in $\left.\mu \mathrm{M}\right)$; (d) ammonium concentrations $\left(\mathrm{NH}_{4}\right.$ in $\left.\mu \mathrm{M}\right)$; (e) phosphate concentrations $\left(\mathrm{PO}_{4}\right.$ in $\mu \mathrm{M}$ ); (f) dissolved organic carbon concentrations (DOC in $\mu \mathrm{M})$; (g) dissolved organic nitrogen concentrations (DON in $\mu \mathrm{M})$; and (h) dissolved organic phosphorus concentrations (DOP in $\mu \mathrm{M})$.

The three rivers were clearly the main source of particulate organic nitrogen and phosphorus in the lagoon (Fig. 3). PON reached a maximum concentration of $9.3 \mu \mathrm{M}$ in the vicinity of the Chumpan Estuary and progressively decreased while spreading to the north (Fig. 3a). Concerning PP, the Palizada River was the main source with concentrations close to $0.9 \mu \mathrm{M}$, progressively decreasing to $0.6 \mu \mathrm{M}$ while spreading along the southern shore toward the Chumpan Estuary and $0.5 \mu \mathrm{M}$ in the northeastern drift toward the Puerto Real passage (Fig. 3b). Significant Spearman's rank correla- tions $(n=35, p<0.05)$ were found between PP and PON ( $\rho=0.73), \mathrm{NO}_{3}(\rho=0.57)$, and salinity $(\rho=-0.56)$.

\subsection{Photosynthetic pigment and activity}

Chlorophyll (Chl) and phaeopigment followed a convergent distribution pattern (Fig. 3c and d) with maximum concentrations close to or in the vicinity of the Palizada River mouth ( $>6 \mu \mathrm{g} \mathrm{Chl} \mathrm{L}^{-1}$ and $\sim 2 \mu \mathrm{g} \mathrm{Phaeo} \mathrm{L}^{-1}$ ). A range of 1$6 \mu \mathrm{g} \mathrm{Chl} \mathrm{L}{ }^{-1}$ and $1-2 \mu \mathrm{g}$ Phaeo $\mathrm{L}^{-1}$ was encountered in the western part of the lagoon. Concentrations $<1 \mu \mathrm{g} \mathrm{Chl} \mathrm{L}-1$ 

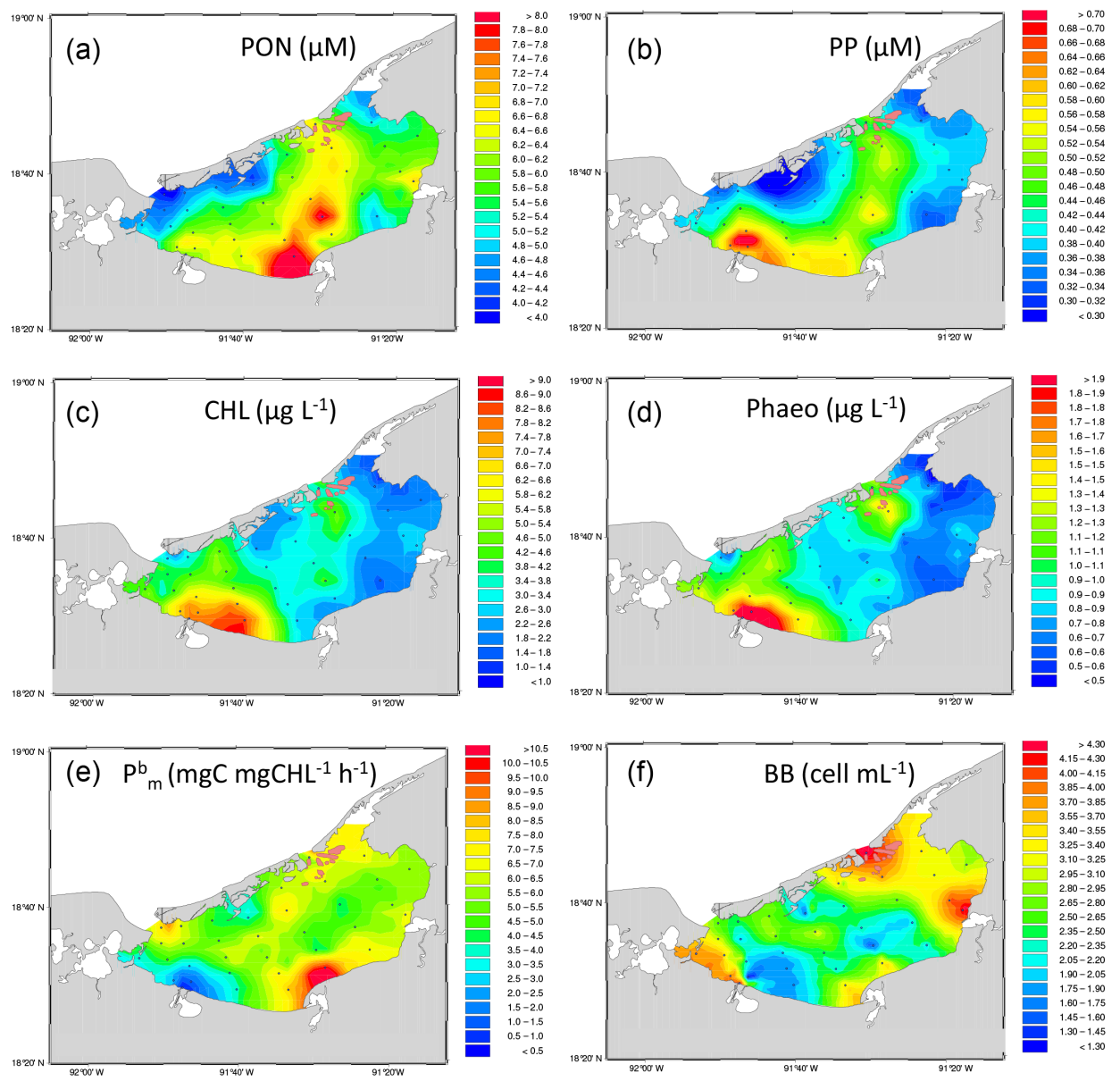

Figure 3. Same as Fig. 2 but for (a) particulate organic nitrogen concentrations (PON in $\mu \mathrm{M})$; (b) particulate organic phosphorus concentrations (PP in $\mu \mathrm{M})$; (c) total chlorophyll concentrations $\left(\mathrm{Chl} \mathrm{in} \mathrm{mg} \mathrm{m}^{-3}\right)$; (d) phaeopigments (Phaeo in $\mathrm{mg} \mathrm{m}^{-3}$ ); (e) maximum photosynthetic rate normalized to chlorophyll $\left(P_{\mathrm{m}}^{b}\right.$ in $\left.\mathrm{mg} \mathrm{C} \mathrm{mg} \mathrm{Chl}^{-1} \mathrm{~h}^{-1}\right)$; and (f) free-living prokaryote abundance $\left(10^{6}\right.$ cell $\left.\mathrm{mL}^{-1}\right)$.

and $1-2 \mu \mathrm{g}$ Phaeo $\mathrm{L}^{-1}$ were mostly confined to the eastern part. On a global view, Phaeo accounted for $28 \pm 8 \%$ of $\mathrm{Chl}$ on average, thus attesting to rather active phytoplankton communities. Significant Spearman's rank correlations $(n=$ $35, p<0.05)$ were found between Chl and Phaeo $(\rho=0.82)$ and $\operatorname{PP}(\rho=0.74)$.

The maximum rate of carbon production per unit of chlorophyll at light saturation $\left(P_{\mathrm{m}}^{b}\right.$, Fig. 3e) was minimal $\left(<0.5 \mathrm{mg} \mathrm{C} \mathrm{mg} \mathrm{Chl}^{-1} \mathrm{~h}^{-1}\right)$ in the Palizada plume in association with the maximum Phaeo: Chl ratio measured $(>44 \%)$. Maximum $P_{\mathrm{m}}^{b}$ values in excess of $8.0 \mathrm{mg} \mathrm{Cmg} \mathrm{Chl}^{-1} \mathrm{~h}^{-1}$ were measured close the Chumpan Estuary in an area with a low Phaeo: Chl ratio $(<25 \%)$.

\subsection{Bacterial abundance and extracellular enzymatic activities}

Free-living prokaryote abundance ranged from 1.0 to $4.8 \times 10^{6}$ cell mL $\mathrm{mL}^{-1}\left(\right.$ mean $=2.8 \times 10^{6}$ cell mL $\mathrm{mL}^{-1}, \mathrm{SD}=0.9 \times$ $10^{6}$ cell $\mathrm{mL}^{-1}, n=35$ ), with maximum values observed in the Puerto Real passage and near the river mouths (Candelaria and Chumpan Rivers) the except for the Palizada River which showed the highest river-lagoon gradient for maximum to minimum values (Fig. 3f).

Cell-specific aminopeptidase (Leu-MCA) and phosphatase (MUF-P) activities reached maximum values near the mouths of the Palizada and Chumpan rivers at 33, and $131.9 \mathrm{fmol} \mathrm{L}^{-1} \mathrm{~h}^{-1}$ cell $^{-1}$, respectively (Fig. 4a and b). Cell-specific lipase activity (MUF-Lip) was at maximum (10.9 fmol L ${ }^{-1} \mathrm{~h}^{-1}$ cell $^{-1}$; Fig. $\left.4 \mathrm{c}\right)$ from the Chumpan River mouth northward towards Carmen Island, crossing the lagoon approximately in the middle following the isotherms (Fig. 2a). Much lower activities were found over most of the lagoon for all the activities (mean values in $\mathrm{fmol} \mathrm{L}^{-1} \mathrm{~h}^{-1}$ cell $^{-1}$ are $12.6 \pm 8.4$ for Leu-MCA, $12.1 \pm 24.2$ for MUF-P, and $2.4 \pm 2.6$ for MUF-Lip). Significant Spearman's rank correlations $(n=35, p<0.01)$ were found between DOC $(\rho=-0.27)$, PON $(\rho=0.33)$, aminopeptidase activities and, to a greater extent, between 
phosphatase activities and $\mathrm{PO}_{4}(\rho=-0.46), \mathrm{PP}(\rho=0.60)$, $\mathrm{NO}_{3}(\rho=0.69)$, and $\mathrm{Chl}(\rho=0.53)$.

\subsection{Dissolved PAH concentrations and estimated abundance of bacterial PAH degraders}

Dissolved total PAH concentrations (Fig. 5a) were higher near the El Carmen Inlet $\left(332 \mathrm{ng} \mathrm{L}^{-1}\right)$ and relatively lower near the Palizada River (187 ng L ${ }^{-1}$ ) and the Chumpan River mouths $\left(166 \mathrm{ng} \mathrm{L}^{-1}\right)$. They were generally lower in the rest of the lagoon $\left(<130 \mathrm{ng} \mathrm{L}^{-1}\right)$. Quantification by MPN counts showed high enrichment of PAH degraders near the Palizada River (estimated at $4.6 \times 10^{4}$ cells $\mathrm{mL}^{-1}$, equivalent to $4.4 \%$ of free-living prokaryotes) (Fig. $5 \mathrm{~b}$ ). Lower values were found near the Chumpan River mouth (estimated at $4.7 \times 10^{3}$ cells $\mathrm{mL}^{-1}$, equivalent to $0.2 \%$ of free-living prokaryotes) and commonly represented less than $0.1 \%$ of the free-living prokaryote abundance in the rest of the lagoon. Quantification by MPN counts showed a significant, though low, Spearman's rank correlation with dissolved total PAH concentrations $(\rho=0.37, p<0.05, n=35)$. MPN count correlations $(p<0.05, n=35)$ were stronger with PP $(\rho=0.65)$ and $\operatorname{Chl}(\rho=0.53)$.

\subsection{Spatial distribution of total and metabolically active bacteria by CE-SSCP fingerprints}

Bacterial community structure defined as a function of $16 \mathrm{~S}$ rDNA-based fingerprints from each sample singled out three individual stations (Palizada River, El Carmen Inlet and Candelaria River) and aggregated five groups of stations (Fig. 6a). Three of these groups included a large number of samples: nine stations located in the northeastern part of the lagoon near the Puerto Real Inlet; nine stations positioned in the middle of the lagoon north from Chumpan River; and eight stations situated to the southwest of Carmen Island. Two other groups with fewer stations identified intermediate communities found between the El Carmen Inlet and the Palizada River in the western part of the lagoon (stations 2, 4, and 6) and the Candelaria River in the middle of the lagoon (stations 22, 24, and 27).

Metabolically active bacterial communities as a function of 16S rRNA-based fingerprints singled out two stations (Palizada River and El Carmen Inlet) and aggregated five groups of stations that were slightly different from the DNA-based clusters (Fig. 6b). Three of these groups included a large number of samples: 15 stations located in the eastern part of the lagoon; 9 stations in the middle of the lagoon north of the Chumpan River; and 5 stations in the northwestern part of the lagoon near the El Carmen Inlet. Two other groups with fewer stations showed intermediate communities found near the Palizada River mouth (stations 6 and 8) and further east (stations 9 and 12).

\subsection{Environmental drivers of the total and active prokaryote community structures}

To analyze the main environmental factors controlling the spatial distribution of total (Fig. 7a) and active (Fig. 7b) prokaryote communities, we performed a canonical correspondence analysis. In both DNA- and RNA-based analyses, the cumulative percentage of variance of the speciesenvironment relationship indicated that the first and second canonical axes explained 48 and $24 \%$ of the total variance for DNA and 45 and $31 \%$ for RNA, respectively. The remaining axes accounted for less than $14 \%$ of the total variance each and thus were not considered as significant enough.

In the DNA-based CCA, the first canonical axis was positively correlated with $\mathrm{NO}_{3}^{-}$and $\mathrm{Chl}$ and negatively correlated with the concentration of DOC, DOP, DON and oxygen. In the RNA-based CCA, the first canonical axis was positively correlated with $\mathrm{NO}_{3}^{-}$and PAHs and negatively correlated with the concentration of POC, PON, oxygen, salinity, $\mathrm{PO}_{4}$, and Chl. The concomitant effect of those parameters explained 27 and $40 \%$ (ratio between the sum of all canonical eigenvalues and the sum of all eigenvalues) of the changes in bacterial community structure found in the DNA- and RNAbased fractions, respectively (Fig. 7).

\section{Discussion}

\subsection{Biogeochemical characteristics of the Términos Lagoon under low river discharge conditions}

With a contribution of about $76 \%$ to the river inputs in the lagoon (Fichez et al., 2016; Jensen et al., 1989), the Palizada River delivers most of the new nitrogen input as nitrate and ammonium. High concentrations of nitrogen were also measured in the Puerto Real Inlet, suggesting a second nitrogen source from coastal seawater. These two sources have clearly different impacts on primary producer development and activity as shown by the Phaeo: Chl ratio $(<20 \%$ in the vicinity of the Palizada River, but $>30 \%$ near the Puerto Real Inlet) and $P_{\mathrm{m}}^{b}$ values (low in the Palizada area and higher near the inlet). Therefore, despite greater chlorophyll degradation (indicated by high Phaeo concentrations), phytoplanktonic cells were more productive under the influence of waters from the Gulf of Mexico when compared to those under the river's influence. Specifically, there were similar nutrient, DOM, and POM concentrations for the two zones, and we measured a similar potential primary production-per-unit volume (27.5 and $30.2 \mathrm{mg} \mathrm{C} \mathrm{m}^{-3} \mathrm{~h}^{-1}$ for the Palizada River and Puerto Real Inlet, respectively). However, the chlorophyll stock was about 2-fold lower in the area of the inlet (6.3 and $3.9 \mathrm{mg} \mathrm{Chl} \mathrm{m}^{-3}$ for the Palizada River and Puerto Real Inlet, respectively). This is in apparent contradiction with what has traditionally been reported on the influence of river inputs, which generally largely enhance primary productivity 

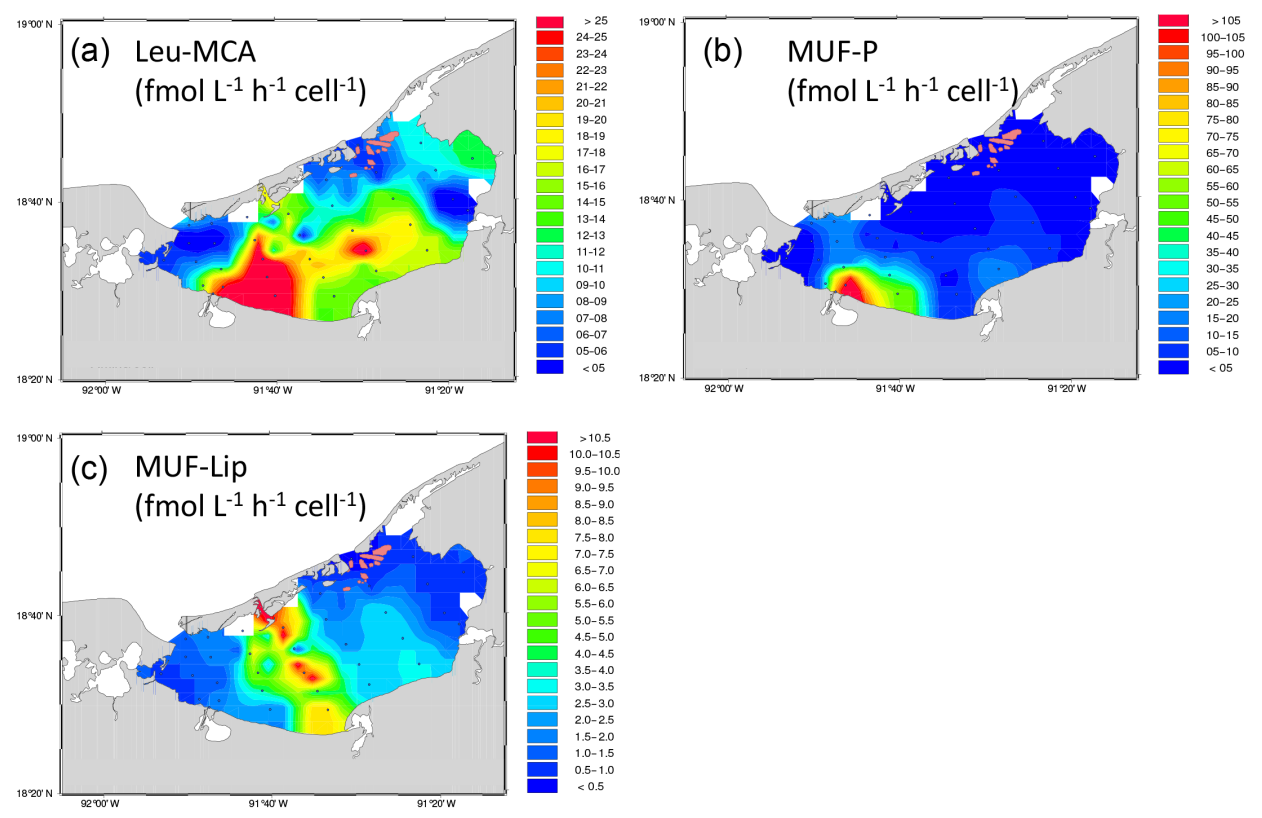

Figure 4. Same as Fig. 2 but for (a) aminopeptidase activities ( $\mathrm{fmol} \mathrm{L}^{-1} \mathrm{~h}^{-1}$ cell $\left.{ }^{-1}\right)$; (b) phosphatase activities $\left(\mathrm{fmol} \mathrm{L}^{-1} \mathrm{~h}^{-1}\right.$ cell $\left.{ }^{-1}\right)$; and (c) lipase activities $\left(\mathrm{fmol} \mathrm{L}-1 \mathrm{~h}^{-1}\right.$ cell $\left.{ }^{-1}\right)$.
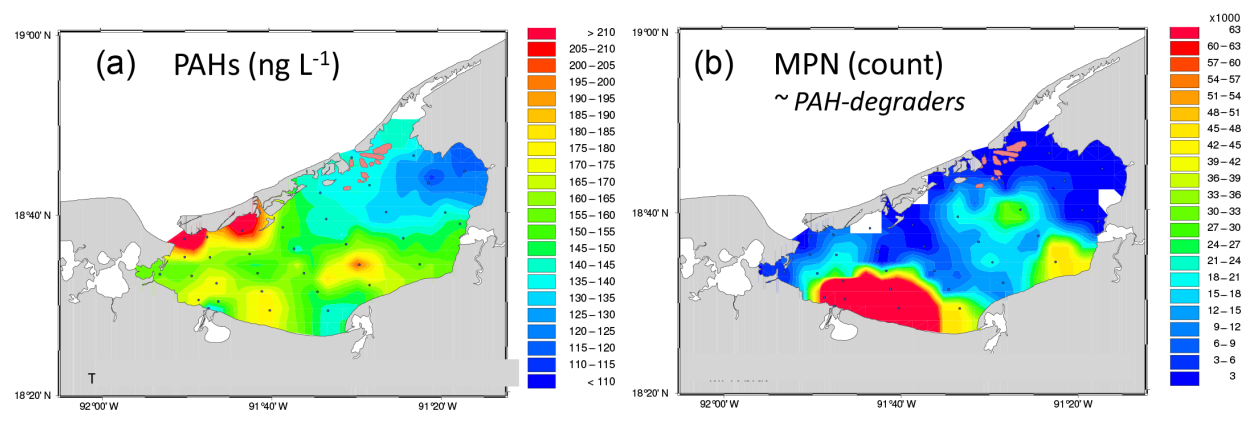

Figure 5. Same as Fig. 2 but for (a) total dissolved PAHs $\left(\mathrm{ng} \mathrm{L}^{-1}\right)$; and (b) the most probable number (MPN count).

(see for example the Rhone River in the Mediterranean Sea; Pujo-Pay et al., 2006), in coastal areas. The decreasing turbidity along the estuarine-to-inlet transect is the first factor explaining the seaward offset of phytoplankton productivity. However, higher grazing activity by herbivores in the coastal waters or in the vicinity of the inlet could be an explanation to further justify the conjunction of higher Phaeo concentrations with active phytoplankton physiology (this requires further study).

Moreover, Day et al. (1982) demonstrated that small additions of filtered mangrove water had a stimulatory effect on pelagic primary production in the Términos Lagoon. This observation was later confirmed by Rivera-Monroy et al. (1998) who also evidenced a large temporal variability in the stimulating effect and a rapid inhibition due to variable humic substance concentrations. The relative decrease of productivity close to the Palizada plume could be due to humic matter, as we also found relatively high concentrations in dis- solved PAHs (see hereafter Sect. 4.4). Finally, it is clear that bottom-up control of the system (by nutrients and/or humic substances) drove the differential responses of phytoplankton productivity in the eastern and western part of the lagoon, probably in conjunction with grazing activity (top-down control).

At the time of our study, the Palizada River and Puerto Real Inlet were major sources of nitrogen for the lagoon. Sediments are generally considered to be a significant internal source of nutrients in shallow coastal ecosystems, but they may also be a net sink of dissolved nitrogen, at least during certain times of the year (Sundbäck et al., 2000; Tyler et al., 2003). Rivera-Monroy et al. (1995a) measured nitrogen fluxes between Estero Pargo (an unpolluted tidal creek), and a fringe mangrove forest in the Términos Lagoon. They reported that mangrove sediments were a sink of $\mathrm{NO}_{3}$ and $\mathrm{NH}_{4}$ throughout the year. Denitrification, the dissimilatory reduction of $\mathrm{NO}_{3}$ to produce $\mathrm{N}_{2} \mathrm{O}$ and $\mathrm{N}_{2}$, was considered the main 


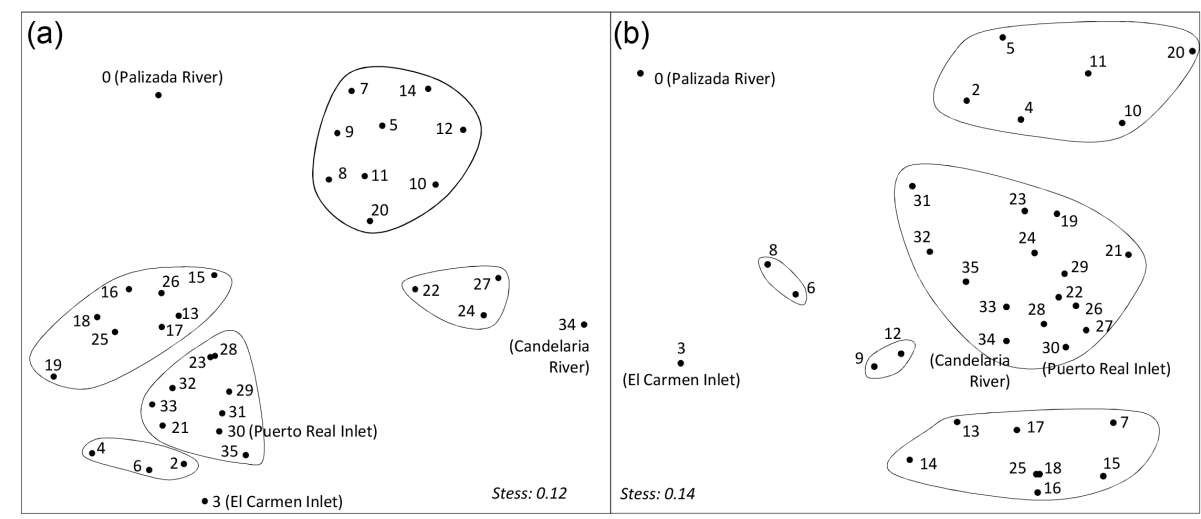

Figure 6. Non-metric multidimensional scaling (NMDS) plot of the (a) total and (b) metabolically active prokaryotic community structures as determined from CE-SSCP profiles based on the Bray-Curtis similarity index. Clusters were determined according to the SIMPROF similarity profile test $(p<0.05)$.

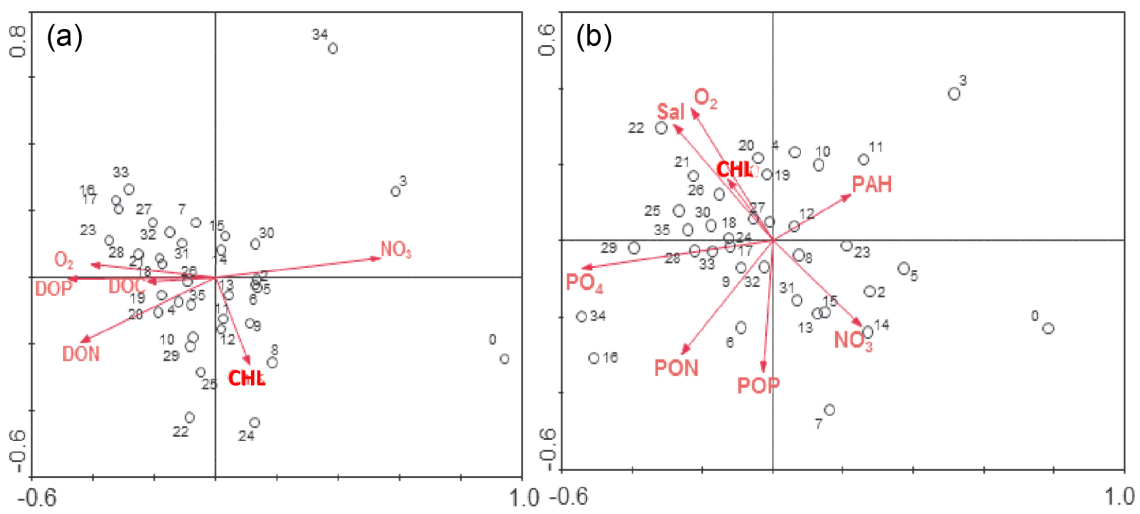

Figure 7. Canonical correspondence analysis of (a) total and (b) active bacterioplankton community structures from the 35 samples using physico-chemical parameters. Arrows point in the direction of increasing values of each variable. The length of the arrows indicates the degree of correlation with the represented axes. The position of samples relative to the arrows is interpreted by projecting the points on the arrow. This indicates the extent to which a sample prokaryotic community composition is influenced by the environmental parameter represented by that arrow. The variance explained by the environmental variables selected by the model represent 27 and $40 \%$ of the variability at the DNA and RNA level, respectively.

process contributing to $\mathrm{NO}_{3}$ loss. However, direct measurements of denitrification rates in the fringe and basin mangroves of the Términos Lagoon indicated a low sink of $\mathrm{NO}_{3}$ (Rivera-Monroy et al., 1995b), contrary to what has been evidenced in other mangrove forests (i.e. Twilley, 2013). This was later confirmed by Rivera-Monroy et al. (2007), who hypothesized that most of the inorganic nitrogen was retained in the sediments and not lost via denitrification. Rivera-Monroy et al. (2007) also measured a decoupling between sources of nitrogen and phosphorus and, because $\mathrm{P}$ is a limiting nutrient, they assumed that the dominant source was from tidal inputs as opposed to remineralization from organic matter in the sediment. During our study, Origel Moreno (2015) found that benthic carbon mineralization consumed a large proportion (between 67 and $86 \%$ ) of the pelagic carbon production. These values are at the upper end of the range calculated for subtropical lagoons (Grenz et al., 2010; Machado and Knop- pers, 1988) and indicate high biological activity in the sediments. Additionally, Origel Moreno (2015) estimated that 50 to $95 \%$ of nitrogen was mineralized in the sediment through various $\mathrm{N}$-consuming processes and that nitrogen was more efficiently mineralized than phosphorus.

Our large-scale study considering the whole lagoon provides some information about the potential origin of phosphorus in the water column. It is clear from our measurements that the phosphate distribution in the lagoon is disconnected from nitrogen. This impacts the stoichiometry of particulate organic matter ( $\mathrm{N}: \mathrm{P}$ ratio) through the whole lagoon, as shown by the surprisingly and relatively low values of the PON : PP ratio $(<13)$ at all stations (indicating a particulate nitrogen deficit), with the exception of those located in the southwest part of the lagoon where a canonical Redfield ratio of 16 was measured (Fig. 8). To sustain their growth requirement, primary producers have the ability 


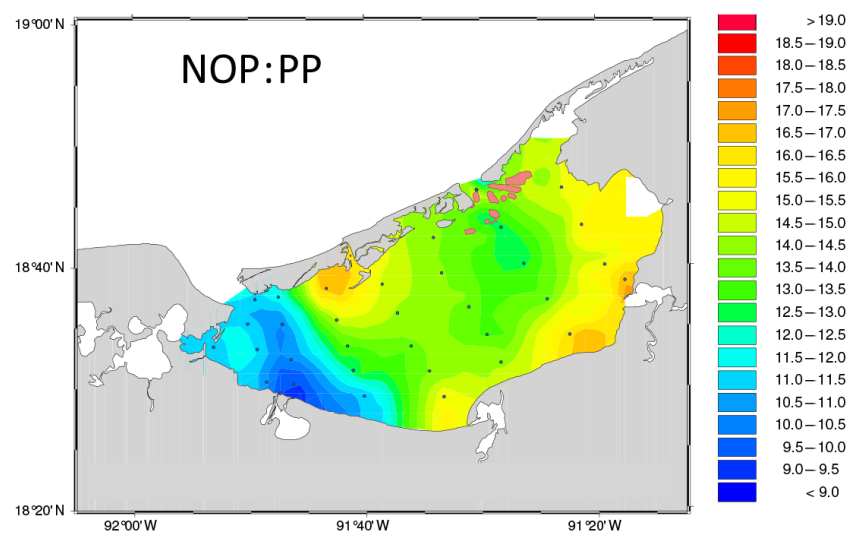

Figure 8. Same as Fig. 2 but for the NOP : PP ratio.

to decouple their consumption of phosphorus and nitrogen with respect to a variable metabolic plasticity (Conan et al., 2007). In comparison to the two previously discussed main sources of $\mathrm{NO}_{3}$ and $\mathrm{NH}_{4}$ (Palizada River and Puerto Real Inlet) located in the western and northern part of the lagoon, we identified two distinct main sources of $\mathrm{PO}_{4}$ in the Términos Lagoon during the sampled period: (i) river inputs from the Candelaria and Chumpan rivers in the south part, even though their contribution to the overall river discharge is low; and (ii) mineralization of organic phosphorus (PP and DOP) by prokaryote activity (coherent with ectoenzymatic activities; see hereafter Sect. 4.2). Note that the major source of PP in the lagoon was the Palizada River whereas accumulation of DOP was measured between the Palizada and Chumpan rivers in the southwest of the lagoon. In this area, distribution of dissolved oxygen was minimal compared to the rest of the lagoon, which is consistent with high rates of organic matter mineralization in the water column. Finally, during our study, the dominant source of $\mathrm{PO}_{4}$ was not tidal flooding as hypothesized by Rivera-Monroy et al. (2007), but rather the mineralization of organic matter by free-living prokaryotes in the water column. If this conclusion appears valid in the context of weak river discharges, further studies will be necessary to test its potential extension to other environmental conditions (rainy periods, river flooding, and tidal amplitude).

\subsection{Relationship between biogeochemical conditions and prokaryotic activities}

Our analysis of biogeochemical trends in the Términos Lagoon has been combined with the study of the spatial distribution of prokaryotic extracellular activity. Bacterial aminopeptidase and lipase extracellular activities play a key role in the transformation of biopolymers into small monomers, since a large part of organic matter is in the form of large molecules whereas small molecules $(<600 \mathrm{Da})$ are only directly assimilable by bacteria (Weiss et al., 1991). The expression of aminopeptidase activity indicates the absence of direct bacterial assimilation of dissolved organic matter and their ability to actively release enzymes outside the cells (Van Wambeke et al., 2009). Moderate but significant negative correlations were found between aminopeptidase activity per cell and DOC concentration in the Términos Lagoon $(\rho=0.27, n=35, p<0.01)$. Higher DOC concentrations associated with lower aminopeptidase activity suggest a higher amount of labile organic matter for bacteria. The high aminopeptidase activity in the Palizada River plume confirmed the presence of recalcitrant organic matter from terrestrial origin, as opposed to minimum activities in Puerto Real marine waters or in the Candelaria River mouth, where DOC concentrations were maximal. Lipase activities showed different trends, with higher activities found in the middle of the lagoon north of the Chumpan River. We previously published results indicating that ambient quantity and quality of hydrolyzable acyl lipids clearly couple with the measurement of their in situ hydrolysis rates (Bourguet et al., 2009). The differences between the spatial distributions of ectoenzymatic aminopeptidase and lipase activities suggest that organic matter from a different composition resided in the central zone of the Términos Lagoon, a result in strong agreement with a recent study on hydrodynamics that identified a large circulation cell in the same central area (Contreras Ruiz et al., 2014). Unfortunately, the contribution of the protein or lipid pool to the total organic matter was not measured at the time of the study, which may have strengthened our hypothesis concerning the role of the composition of organic matter in the spatial distribution of extracellular enzyme activities. This lack of information may explain the very low or absent correlation found between extracellular activities and measured biogeochemical parameters.

Phosphatase activity is well known to be controlled by the availability of soluble reactive phosphorus (Van Wambeke et al., 2009). This activity was essentially observed in the vicinity of the Palizada River, which is the main source of PP in the lagoon. However, in the Puerto Real Inlet, which includes the two $\mathrm{PO}_{4}$-depleted zones which indirectly influence the stoichiometry of particulate organic matter as discussed above (Fig. 8). Thus, a zone with clear phosphatase activity but which is P-depleted indicates a very low $\mathrm{P}$ availability for phytoplanktonic growth. This is consistent with the low phytoplankton productivity observed, indicating weak $\mathrm{C}$ fixation rates in the Palizada River mouth which strengthens our bottom-up control hypothesis. Extracellular phosphatase activity was significantly $(p<0.05, n=35)$ negatively correlated with $\mathrm{PO}_{4}(\rho=-0.46)$ and positively correlated with PP $(\rho=0.60)$. Our data therefore converge with the model previously proposed by Robadue et al. (2004) which predicted a different behavior between the eastern and western sides of the lagoon in terms of both water budget and ecosystem functioning. This distinction is mostly driven by the respective influences of the Palizada River discharge in the west and the Puerto Real marine water inputs in the northeast. 


\subsection{Prokaryotic community structure and ectoenzyme activities}

Molecular fingerprinting (such as CE-SSCP) and nextgeneration sequencing technologies generally yield converging results (Ghiglione et al., 2005; Ghiglione and Murray, 2012; Ortega-Retuerta et al., 2012; Sauret et al., 2015), evidencing clear shifts in bacterial community structure as a function of changes in biogeochemical characteristics (Ghiglione et al., 2005). Numerous factors can regulate microorganism population dynamics, often simultaneously, and the literature contains evidence (Berdjeb et al., 2011; Fuhrman et al., 2013; Ghiglione et al., 2008) underlining the importance of relevant statistical analyses to investigate the relative importance of environmental factors in predicting bacterial community dynamics. It is generally recognized that the expression of ectoenzyme activities could result from species selection and population dynamics (Martinez et al., 1996), and the zonation of prokaryotic community structure in the eastern, middle, and western parts of the lagoon agree with such a paradigm. The community composition in the eastern part could be divided into two sub-clusters corresponding to the respective influences of the Palizada River mouth and El Carmen Inlet. Both DNA- and RNA-based fingerprinting show that the Palizada River and El Carmen Inlet hosted distinct prokaryotic communities, as previously observed in transition zones such as rivers (Ortega-Retuerta et al., 2012) or lagoon mouths (Rappé et al., 2000). The relationship between community composition and ectoenzyme activities was particularly evident when the lipase and aminopeptidase rates were considered. Lipase activity was magnified in the middle of the lagoon, with a south to north increasing gradient from the Chumpan River to Carmen Island that coincided with specific communities (cluster II in both DNA- and RNA-based fingerprinting). Other communities were found in the western part under the influence of the Palizada River where higher aminopeptidase activity was measured.

The combination of DNA and RNA strengthens our observations as DNA-based analysis alone would have failed to distinguish between active, dormant, senescent, or dead cells and would thus prevent the assessment of the level of activity of each detected bacterial population (Rodríguez-Blanco et al., 2010). Even though the abundance of bacteria in the sea is high, only a small fraction is considered to be metabolically active (Del Giorgio and Bouvier, 2002). Bacterial growth rate has been shown to correlate with cellular rRNA content (Kemp et al., 1993); therefore, information on cellular activity may be obtained by tracking reverse-transcribed 16S rRNA (Lami et al., 2009). In the present study, we focused on the free-living prokaryotes and disregarded the particle-attached fraction by pre-filtering the water by $3 \mu \mathrm{m}$. This allowed us to eliminate the problem of DNA eukaryotic chloroplasts which may have biased our results in the context of the gradients of productive zones. The combination of DNA and RNA results in the Términos Lagoon showed similar trends, with total and active communities presenting a strong zonation between the eastern, middle, and western parts of the lagoon in addition to the smaller transition zones located around major sources of coastal (El Carmen Inlet) and river inputs (Palizada and Candelaria). Here, the combination of DNA and RNA showed similar tendencies within the total and active communities presenting the eastern, middle, and western distribution across the lagoon. These results indicate that most of the free-living bacterial communities detected by molecular fingerprinting (DNA-based) were active (RNA-based) within the lagoon, with the exception of the local transition zones between the lagoon waters in the coastal (El Carmen Inlet) or river areas (Palizada and Candelaria).

\subsection{Biogeochemical parameters and PAHs drive the prokaryotic community structure}

Through the use of direct gradient multivariate ordination analyses, we demonstrate that a complex array of biogeochemical parameters was the driving force behind prokaryotic community structure shifts in the Términos Lagoon. Physico-chemical parameters such as nitrate, oxygen, dissolved organic matter (DOC, DON, DOP), and chlorophyll $a$ acted in synergy to explain bacterial assemblage changes in rDNA level. Some differences were observed to explain the geographical patterns of the metabolically active bacterial communities (rRNA level). Indeed, salinity, particulate organic matter (PON, PP), and phosphate were needed in addition to the nitrate, oxygen, and Chl parameters already outlined in the rDNA level. The variance explained by the environmental variables selected by the statistical model represented 27 and $40 \%$ of the variability at the DNA and RNA level, respectively. Further studies are therefore needed to elucidate the unexplained variance of the model due to other parameters not taken into account in our study, such as the ecological relationships between bacterial communities themselves or top-down control by predation and viral lysis (Ghiglione et al., 2016).

The concentration of dissolved total PAHs was also a significant explanatory variable of the metabolically active bacterial community structure. PAHs are considered the most toxic component of crude oil to marine life and are ubiquitous pollutants in the coastal environment (Kennish, 1992). Our study was performed just before the 2010 Deepwater Horizon blowout in the Gulf of Mexico, but several offshore oil platforms exist in the shallow waters of the Campeche Bank in the southern part of the Gulf of Mexico, for example in the Campeche field (Cheek-1) which is only $60 \mathrm{~km}$ north of the Términos Lagoon (Warr et al., 2013). The coast of Campeche itself was also impacted by the 1979 Ixtoc I platform oil spill, roughly $100 \mathrm{~km}$ northwest of the Términos Lagoon (Warr et al., 2013). PAH concentrations in the Términos Lagoon indicated an input into the lagoon from the El Car- 
men Inlet (maximal concentration of $332 \mathrm{ng} \mathrm{L}^{-1}$ ) that mostly impacted the eastern part, with concentration $<130 \mathrm{ng} \mathrm{L}^{-1}$ in the rest of the lagoon. We observed a high enrichment of PAH degraders in the southeastern part of the lagoon, with a low but significant correlation with PAH concentrations ( $\rho=0.37, p<0.05, n=35)$. This enrichment was particularly high (estimated at $4.6 \times 10^{4}$ cell $\mathrm{mL}^{-1}$ and equivalent to $4.4 \%$ of the free-living prokaryotes abundance) in the Palizada River mouth. Nitrogen fertilization from allochthonous inputs from the Palizada River may be crucial for PAH degradation potential in the Términos Lagoon. Indeed, it is well accepted that bacterial degradation of hydrocarbons (carbon source for bacteria) is dependent on nutrients to re-equilibrate the $\mathrm{C}: \mathrm{N}: \mathrm{P}$ ratio (Sauret et al., 2015, 2016). Some halotolerant bacteria such as Marinobacter hydrocarbonoclasticus sp. 17 (Grimaud et al., 2012) may have the capability to degrade PAHs and survive in rivers, lagoons, and seawater. Further studies using PAH-stable isotopes coupled with pyrosequencing (Dombrowski et al., 2016; Sauret et al., 2016) are necessary to identify the dynamics of these functional communities in the Términos Lagoon. Using similar approaches, previous reports have shown that the pollutant content and PAHs, in particular, were responsible for the bacterial community structure dynamic in the sediment of the Bizerte Lagoon, Tunisia (Ben Said et al., 2010). Such a massive impact of pollutants was not observed here, possibly because of the difference in the degree of pollution between the two areas (moderately contaminated in the Términos Lagoon versus highly contaminated in Bizerte). The metabolically active bacterial community structure in the Términos Lagoon was significantly impacted by PAH pollution, even though it did not exceed the effect of other environmental parameters and their specificity at each geographical location.

\section{Conclusions}

This study provides a new original set of biogeochemical characteristics for one of the largest shallow tropical coastal lagoons. Due to the 2009-2010 El Niño Modoki episode, climatic conditions in the Términos Lagoon region were exceptionally dry at the time of our sampling, hence potentially indicative of future environmental conditions resulting from the predicted trends in climate change in the Central American region. We evidenced a clear distinction in ecosystem functioning between the eastern and western parts of the lagoon. Most of the oceanic water entering through the inlets spread toward the southeast where dissolved organic matter accumulated. This area did not support significant phytoplankton development. In the west, we hypothesized a balance shift between top-down and bottom-up control to explain the different responses in terms of phytoplankton productivity. The decoupling between nitrogen inputs brought by oceanic waters, the Palizada River, and phosphate inputs from the Chumpan River did not allow for phytoplank- ton C fixation. Most of the phytoplankton biomass was aggregated around the Palizada River mouth (which carried most of the freshwater into the lagoon) in a P-depleted area (low phosphate concentration and high bacterial phosphatase activity). Bacterial ectoenzyme activities were mainly observed in the middle of the lagoon along a south to north cross section stretching from the Chumpan River up to Carmen Island. Maximum mineralization activities were found in this area, which coincided with high extracellular lipase and aminopeptidase activities and low DOC and $\mathrm{O}_{2}$ concentrations. The lagoon produced significant quantities of particulate and dissolved organic matter thanks to the (i) nutrient inputs from the rivers, (ii) uncoupling between nitrogen and phosphate, and (iii) the prokaryotic activities. However, in the end, most of this autochthonous matter was internally processed or stored and only a little was exported to the Gulf of Mexico's coastal waters. Therefore, during our study, the water column of the Términos Lagoon functioned globally as a kind of nitrogen assimilator. The highest PAH concentrations were measured in the El Carmen Inlet, suggesting anthropogenic pollution in this zone which is probably related to the oil-platform exploitation activities in the shallow waters to the south of the Gulf of Mexico and, more locally, to the efflux from the El Carmen harbor which serves as a logistical support to the oil extraction industry. We also evidenced the importance of nitrogen fertilization from the Palizada River, which seems to support an abundant prokaryotic community of PAH degraders.

Another significant outcome of our study has been to (i) link the spatial distribution of ectoenzymatic activities with changes in prokaryotic community structure and (ii) show that a combination of a complex set of physical and biogeochemical parameters was necessary to explain the changes in prokaryotic community structure. This study also emphasizes the use of direct multivariate statistical analyses to keep the influence of pollutants in perspective without denying the role of other physico-chemical variables to explain the dynamics of prokaryotic community structure in polluted areas.

Our study provides an extensive dataset efficiently mixing biogeochemical status with information on phytoplankton and prokaryotic structure and dynamics. This has never before been measured in the Términos Lagoon and the outcome offers a strong base of information and reflection for future studies on this essential coastal system and into the potential environmental conditions which might prevail as a consequence of future climate change. Further studies are needed to compare our dataset with high river input regime conditions and asses both how this might affect the observed uncoupling between nitrogen and phosphate and the dominant source of phosphorus and its consequences on primary production and prokaryotic activities. Finally, the role of topdown control should also be investigated in order to better understand the variability of the observed responses. 
Data availability. Data for this paper are now referenced in doi:10.13140/RG.2.2.18609.99680.

Competing interests. The authors declare that they have no conflict of interest.

Acknowledgements. The present work was conducted within the frame of the Joint Environmental Study of the Términos Lagoon (JEST) and jointly financed by the French National Program EC2CO-DRIL, the Institut de Recherche pour le Développement (IRD), the Centre National de la Recherche Scientifique (CNRS), the University of "Université de Lille-I", and the Universidad Autónoma Metropolitana-Iztapalapa (UAM-I). The authors are extremely grateful to the Instituto de Ciencias del Mar y Limnologia and the Universidad Nacional Autónoma de México (ICML-UNAM) for providing full access to their field station in Ciudad del Carmen. We also acknowledge P. A. and M. V. Ghighi for carefully proofreading. Thanks also to Julia, Joan, and Vivien for their support. M. Origel-Moreno was financially supported by Bonafont S. A De .C.V. and CONACyT during her PhD work.

Edited by: C. Woulds

Reviewed by: two anonymous referees

\section{References}

Abreu, P. C., Biddanda, B. B., and Odebrecht, C.: Bacterial dynamics of the Patos Lagoon estuary, southern Brazil $\left(32^{\circ} \mathrm{S}, 52^{\circ} \mathrm{W}\right)$ : Relationship with phytoplankton production and suspended material, Estuarine, Coastal and Shelf Science, 35, 621-635, 1992.

Aguayo, P., Gonzalez, C., Barra, R., Becerra, J., and Martinez, M.: Herbicides induce change in metabolic and genetic diversity of bacterial community from a cold oligotrophic lake, World J. Microb. Biot., 30, 1101-1110, 2014.

Alexander, M.: Most probable number method for microbial populations, in: Methods of Soil Analysis, edited by: Page, A. L., Miller, R. H., and Keeney, D. R., American Society of Agronomy, Madison, WI, 815-820, 1982.

Amado, A. M., Meirelles-Pereira, F., Vidal, L. O., Sarmento, H., Suhett, A. L., Farjalla, V. F., Cotner, J. B., and Roland, F.: Tropical freshwater ecosystems have lower bacterial growth efficiency than temperate ones, Front Microbiol., 4, doi:10.3389/fmicb.2013.00167, 2013.

Aminot, A. and Kérouel, R.: Dosage automatique des nutriments dans les eaux marines. Méthodes en flux continu, Ed IfremerQuae, 2007.

Arnosti, C. and Steen, A. D.: Patterns of extracellular enzyme activities and microbial metabolism in an Arctic fjord of Svalbard and in the northern Gulf of Mexico: contrasts in carbon processing by pelagic microbial communities, Frontiers in Microbiology, 4, doi:10.3389/fmicb.2013.00318, 2013.

Arnosti, C., Steen, A. D., Ziervogel, K., Ghobrial, S., and Jeffrey, W. H.: Latitudinal Gradients in Degradation of Marine Dissolved Organic Carbon, PLoS ONE, 6, e28900, doi:10.1371/journal.pone.0028900, 2011.
Ben Said, O., Goni-Urriza, M., El Bour, M., Aissa, P., and Duran, R.: Bacterial community structure of sediments of the bizerte lagoon (Tunisia), a southern Mediterranean coastal anthropized lagoon, Microb. Ecol., 59, 445-456, 2010.

Berdjeb, L., Ghiglione, J. F., Domaizon, I., and Jacquet, S.: A 2Year Assessment of the Main Environmental Factors Driving the Free-Living Bacterial Community Structure in Lake Bourget (France), Microb. Ecol., 61, 941-954, 2011.

Bourguet, N., Goutx, M., Ghiglione, J.-F., Pujo-Pay, M., Mével, G., Momzikoff, A., Mousseau, L., Guigue, C., Garcia, N., Raimbault, P., Pete, R., Oriol, L., and Lefèvre, D.: Lipid biomarkers and bacterial lipase activities as indicators of organic matter and bacterial dynamics in contrasted regimes at the DYFAMED site, NW Mediterranean, Deep Sea Res. Pt. II, 56, 1454-1469, 2009.

Brosius, J., Dull, T. J., Sleeter, D. D., and Noller, H. F.: Gene organization and primary structure of a ribosomal RNA operon from Escherichia coli, J. Mol. Biol., 148, 107-127, 1981.

Cauwet, G.: Determination of dissolved organic carbon (DOC) and nitrogen (DON) by high temperature combustion, in: Methods of seawater analysis, edited by: Grashoff, K., Kremling, K., and Ehrhard, M., 1999.

Cincinelli, A., Stortini, A. M., Perugini, M., Checchini, L., and Lepri, L.: Organic pollutants in sea-surface microlayer and aerosol in the coastal environment of Leghorn - (Tyrrhenian Sea), Mar. Chem., 76, 77-98, 2001.

Cole, J. J., Findlay, S., and Pace, M. L.: Bacterial production in fresh and saltwater ecosystems: a cross-system overview, Marine ecology progress series, Oldendorf, 43, 1-10, 1988.

Conan, P., Turley, C. M., Stutt, E., Pujo-Pay, M., and Van Wambeke, F.: Relationship between Phytoplankton Efficiency and the Proportion of Bacterial Production to Primary Production in the Mediterranean Sea, Aquat. Microb. Ecol., 17, 131-144, 1999.

Conan, P., Søndergaard, M., Kragh, T., Thingstad, F., Pujo-Pay, M., Williams, P. J. 1. B., Markager, S., Cauwet, G., Borch, N. H., Evans, D., and Riemann, B.: Partitioning of organic production in marine plankton communities: The effects of inorganic nutrient ratios and community composition on new dissolved organic matter, Limnol. Oceanogr., 52, 753-765, 2007.

Contreras Ruiz Esparza, A., Douillet, P., and Zavala-Hidalgo, J.: Tidal dynamics of the Terminos Lagoon, Mexico: observations and 3D numerical modelling, Ocean Dynam., 64, 1349-1371, 2014.

David, L. T.: Laguna de Términos, Campeche, Netherlands Institute for Sea Research, Texel, NL, 9-15, 1999.

David, L. T. and Kjerfve, B.: Tides and currents in a two-inlet coastal lagoon: Laguna de Términos, México, Cont. Shelf Res., 18, 1057-1079, 1998.

Day, J. W. J., Day, R. H., Barreiro, M. T., Ley-Lou, F., and Madden, C. J.: Primary production in the Laguna de Terminos, a tropical estuary in the southern Gulf of Mexico, Oceanol. Acta, 5, 269276, 1982.

Del Giorgio, P. A. and Bouvier, T. C.: Linking the physiologic and phylogenetic successions in free-living bacterial communities along an estuarine salinity gradient, Limnol. Oceanogr., 47, 471-486, 2002.

Dombrowski, N., Donaho, J. A., Gutierrez, T., Seitz, K. W., Teske, A. P., and Baker, B. J.: Reconstructing metabolic pathways of hydrocarbon-degrading bacteria from the Deep- 
water Horizon oil spill, Nature Microbiology, 1, 16057, doi:10.1038/nmicrobiol.2016.57, 2016.

Ferguson, R. L., Buckley, E., and Palumbo, A.: Response of marine bacterioplankton to differential filtration and confinement, Appl. Environ. Microb., 47, 49-55, 1984.

Fichez, R., Archundia, D., Grenz, C., Douillet, P., Gutiérrez Mendieta, F., Origel Moreno, M., Denis, L., Contreras Ruiz Esparza, A., and Zavala-Hidalgo, J.: Global climate change and local watershed management as potential drivers of salinity variation in a tropical coastal lagoon (Laguna de Terminos, Mexico), Aquat. Sci., doi:10.1007/s00027-016-0492-1, in press, 2017.

Fitzwater, S. E., Knauer, G. A., and Martin, J.-M.: Metal contamination and its effect on primary production measurements, Limnol. Oceanogr., 27, 544-551, 1982.

Fuhrman, J., Follows, M., and Forde, S.: Applying “-omics” Data in Marine Microbial Oceanography, Eos, Transactions American Geophysical Union, 94, 241-241, 2013.

García-Ríos, V., Alpuche-Gual, L., Herrera-Silveira, J., MonteroMuñoz, J., Morales-Ojeda, S., Pech, D., Cepeda-González, M. F., Zapata-Pérez, O., and Gold-Bouchot, G.: Towards a coastal condition assessment and monitoring of the Gulf of Mexico Large Marine Ecosystem (GoM LME): Terminos Lagoon pilot site, Environmental Development, 7, 72-79, 2013.

Ghiglione, J. F. and Murray, A. E.: Pronounced summer to winter differences and higher wintertime richness in coastal Antarctic marine bacterioplankton, Environ. Microbiol., 14, 617-629, 2012.

Ghiglione, J.-F., Philippot, L., Normand, P., Lensi, R., and Potier, P.: Disruption of narG, the gene encoding the catalytic subunit of respiratory nitrate reductase, also affects nitrite respiration in Pseudomonas fluorescens YT101, J. Bacteriol., 181, 5099-5102, 1999.

Ghiglione, J.-F., Larcher, M., and Lebaron, P.: Spatial and temporal scales of variation in bacterioplankton community structure in the NW Mediterranean Sea, Aquat. Microb. Ecol., 40, 229-240, 2005.

Ghiglione, J. F., Palacios, C., Marty, J. C., Mével, G., Labrune, C., Conan, P., Pujo-Pay, M., Garcia, N., and Goutx, M.: Role of environmental factors for the vertical distribution $(0-1000 \mathrm{~m})$ of marine bacterial communities in the NW Mediterranean Sea, Biogeosciences, 5, 1751-1764, doi:10.5194/bg-5-1751-2008, 2008.

Ghiglione, J.-F., Martin-Laurent, F., and Pesce, S.: Microbial ecotoxicology: an emerging discipline facing contemporary environmental threats, Environ. Sci. Pollut. Res., 23, 3981-3983, 2016.

González-Gaya, B., Fernandez-Pinos, M.-C., Morales, L., Mejanelle, L., Abad, E., Pina, B., Duarte, C. M., Jimenez, B., and Dachs, J.: High atmosphere-ocean exchange of semivolatile aromatic hydrocarbons, Nat. Geosci., 9, 438-442, 2016.

Grenz, C., Denis, L., Pringault, O., and Fichez, R.: Spatial and seasonal variability of sediment oxygen consumption and nutrient fluxes at the sediment water interface in a sub-tropical lagoon (New Caledonia), Mar. Pollut. Bull., 61, 399-412, 2010.

Grimaud, R., Ghiglione, J.-F., Cagnon, C., Lauga, B., Vaysse, P.J., Rodriguez-Blanco, A., Mangenot, S., Cruveiller, S., Barbe, V., Duran, R., Wu, L.-F., Talla, E., Bonin, P., and Michotey, V.: Genome Sequence of the Marine Bacterium Marinobacter hydrocarbonoclasticus SP17, Which Forms Biofilms on Hydrophobic Organic Compounds, J. Bacteriol., 194, 3539-3540, 2012.
Gullian-Klanian, M., Herrera-Silveira, J. A., Rodríguez-Canul, R., and Aguirre-Macedo, L.: Factors associated with the prevalence of Perkinsus marinus in Crassostrea virginica from the southern Gulf of Mexico, Dis. Aquat. Organ., 79, 237-247, 2008.

Gutierrez, T., Rhodes, G., Mishamandani, S., Berry, D., Whitman, W. B., Nichols, P. D., Semple, K. T., and Aitken, M. D.: Polycyclic aromatic hydrocarbon degradation of phytoplanktonassociated Arenibacter spp. and description of Arenibacter algicola sp. nov., an aromatic hydrocarbon-degrading bacterium, Appl. Environ. Microb., 80, 618-628, 2014.

Hauenstein, E. and Ramírez, C.: The influence of salinity on the distribution of Egeria densa in the Valdivian river basin Chile, Arch. Hydrobiol., 1074, 511-519, 1986.

Head, I. M., Jones, D. M., and Roling, W. F.: Marine microorganisms make a meal of oil, Nature reviews, Microbiology, 4, 173$182,2006$.

Hobbie, J. E.: A comparison of the ecology of planktonic bacteria in fresh and salt water, Limnol. Oceanogr., 33, 750-764, 1988.

Holmes, R. M., Aminot, A., Kérouel, R., Hooker, B. A., and Peterson, B. J.: A simple and precise method for measuring ammonium in marine and freshwater ecosystems, Can. J. Fish. Aquat. Sci., 56, 1801-1808, 1999.

Hoppe, H. G., Arnosti, C., and Herndl, G. J.: Ecological significance of bacterial enzymes in the marine environment, in: Enzymes in the Environment: Activity, Ecology, and Applications, edited by: Burns, R. G. and Dick, R. P., Taylor \& Francis, Marcel Dekker: New York, NY, USA, 2002.

Hsieh, W.-C., Chen, C.-C., Shiah, F.-K., Hung, J.-J., Chiang, K.P., Meng, P.-J., and Fan, K.-S.: Community Metabolism in a Tropical Lagoon: Carbon Cycling and Autotrophic Ecosystem Induced by a Natural Nutrient Pulse, Environ. Eng. Sci., 29, 776782, 2012.

Jassby, A. D. and Platt, T.: Mathematical formulation of the relationship between photosynthesis and light for phytoplankton, Limnol. Oceanogr., 21, 540-547, 1976.

Jensen, J. R., Kjerfve, B., Ramsey III, E. W., Magill, K. E., Medeiros, C., and Sneed, J. E.: Remote sensing and numerical modeling of suspended sediment in Laguna de terminos, Campeche, Mexico, Remote Sens. Environ., 28, 33-44, 1989.

Jiménez, N., Viñas, M., Guiu-Aragonés, C., Bayona, J. M., Albaigés, J., and Solanas, A. M.: Polyphasic approach for assessing changes in an autochthonous marine bacterial community in the presence of Prestige fuel oil and its biodegradation potential, Appl. Microbiol. Biot., 91, 823-834, 2011.

Kemp, P. F., Lee, S., and Laroche, J.: Estimating the growth rate of slowly growing marine bacteria from RNA content, Appl. Environ. Microb., 59, 2594-2601, 1993.

Kennish, M. J.: Polynuclear aromatic hydrocarbons, Ecology of estuaries: anthropogenic effects, CRC Press, Boca Raton, 1992.

Lami, R., Ghiglione, J.-F., Desdevises, Y., West, N. J., and Lebaron, P.: Annual patterns of presence and activity of marine bacteria monitored by $16 \mathrm{~S}$ rDNA-16S rRNA fingerprints in the coastal NW Mediterranean Sea, Aquat. Microb. Ecol., 54, 199-210, doi:10.3354/ame01264, 2009.

Lizárraga-Partida, M. L., Muñoz-Rubio, J., Porras-Aguirre, J., Izquierdo-Vicuna, F. B., and Wong Chang, I.: Taxonomy and distribution of hydrocarbonoclastic bacteria from the Ixtoc-1 area, GERBAM - Deuxième Colloque International de Bactériologie marine, 633-638, 1986. 
Lizárraga-Partida, M. L., Carballo Cruz, R., Izquierdo-Vicuna, F. B., Colwell, R. R., and Chang, I. W.: Bacteriologia de la Laguna de Terminos, Campeche, Mexico, Anales del Instituto de Ciencias del Mar y Limnologi, 14, 97-108, 1987.

Lorenzen, C. J.: A method for the continuous measurement of in vivo chlorophyll concentration, Deep Sea Res. Ocean. Abstr., 13, 223-227, 1966.

MacCord, F., Azevedo, F. D. A., Esteves, F. A., and Farjalla, V. F.: Regulation of bacterioplankton density and biomass in tropical shallow coastal lagoons, Acta Limnologica Brasiliensia, 25, 224-234, 2013.

Machado, E. C. and Knoppers, B. A.: Sediment oxygen consumption in an organic-rich, subtropical lagoon, Brazil, Sci. Total Environ., 75, 341-349, 1988.

Marker, A. F. H.: The use of acetone and methanol in the estimation of chlorophyll in the presence of phaeophytin, Freshwater Biol., 2, 361-385, 1972.

Martinez, J., Smith, D. C., Steward, G. F., and Azam, F.: Variability in ectohydrolytic enzyme activities of pelagic marine bacteria and its significance for substrate processing in the sea, Aquat. Microb. Ecol., 10, 223-230, 1996.

Mével, G., Vernet, M., Goutx, M., and Ghiglione, J. F.: Seasonal to hour variation scales in abundance and production of total and particle-attached bacteria in the open NW Mediterranean Sea (0-1000 m), Biogeosciences, 5, 1573-1586, doi:10.5194/bg-51573-2008, 2008.

Milessi, A. C., Danilo, C., Laura, R.-G., Daniel, C., Javier, S., and Rodríguez-Gallego, L.: Trophic mass-balance model of a subtropical coastal lagoon, including a comparison with a stable isotope analysis of the food-web, Ecol. Model., 221, 2859-2869, 2010.

Noreña-Barroso, E., Gold-Bouchot, G., and Sericano, J. L.: Polynuclear aromatic hydrocarbons in American oysters Crassostrea virginica from the Terminos Lagoon, Campeche, Mexico, Mar. Pollut. Bull., 38, 637-645, 1999.

Origel Moreno, M.: Variabilité spatiale et temporelle des cycles biogéochimiques à l'interface eau-sédiment dans la lagune de Términos, Mexique, 2015, Thèse de doctorat, Institut Méditerranéen d'Océanologie, Université d'Aix-Marseille, Ecole Doctorale des Sciences de l'Environnement, 250 pp., 2015.

Ortega-Retuerta, E., Jeffrey, W. H., Babin, M., Bélanger, S., Benner, R., Marie, D., Matsuoka, A., Raimbault, P., and Joux, F.: Carbon fluxes in the Canadian Arctic: patterns and drivers of bacterial abundance, production and respiration on the Beaufort Sea margin, Biogeosciences, 9, 3679-3692, doi:10.5194/bg-9-36792012, 2012.

Osten-von Rendon, J., Memije, M., Ortiz, A., and Benitez, J.: Potential sources of PAHs in sediments from Terminos lagoon, Campeche, Mexico, Toxicology Letters, 172, Supplement, S162, 2007.

Pedrós-Alió, C., Calderón-Paz, J. I., MacLean, M. H., Medina, G., Marrasé, C., Gasol, J. M., and Guixa-Boixereu, N.: The microbial food web along salinity gradients, FEMS Microbiol. Ecol., 32, 143-155, 2000.

Pujo-Pay, M. and Raimbault, P.: Improvment of the wet-oxydation procedure for simultaneous determination of particulate organic nitrogen and phosphorus collected on filters, Mar. Ecol.-Prog. Ser., 105, 203-207, 1994.
Pujo-Pay, M., Conan, P., and Raimbault, P.: Excretion of dissolved organic nitrogen by phytoplankton assessed by wet oxidation and N-15 tracer procedures, Mar. Ecol.-Prog. Ser., 153, 99-111, 1997.

Rappé, M. S., Vergin, K., and Giovannoni, S. J.: Phylogenetic comparisons of a coastal bacterioplankton community with its counterparts in open ocean and freshwater systems, FEMS Microbiol. Ecol., 33, 219-232, 2000.

Rivera-Monroy, V. H., Day, J. W., Twilley, R. R., Vera-Herrera, F., and Coronado-Molina, C.: Flux of nitrogen and sediment in a fringe mangrove forest in terminos lagoon, Mexico, Estuarine, Coastal and Shelf Science, 40, 139-160, 1995a.

Rivera-Monroy, V. H., Twilley, R. R., Boustany, R. G., Day, J. W., Vera-Herrera, F., and del Carmen Ramirez, M.: Direct denitrification in mangrove sediments in Terminos Lagoon, Mexico, Mar. Ecol.-Prog. Ser., 126, 97-109, 1995b.

Rivera-Monroy, V. H., Madden, C. J., Day, J. W., Twilley, R. R., Vera-Herrera, F., and Alvarez-Guillén, H.: Seasonal coupling of a tropical mangrove forest and an estuarine water column: enhancement of aquatic primary productivity, Hydrobiologia, 379, 41-53, 1998.

Rivera-Monroy, V. H., de Mutsert, K., Twilley, R. R., CastañedaMoya, E., Romigh, M. M., Davis, I., and Stephen E.: Patterns of nutrient exchange in a riverine mangrove forest in the Shark River Estuary, Florida, USA, Hidrobiológica, 17, 169-178, 2007.

Robadue, D. J., Oczkowski, A., Calderon, R., Bach, L., and Cepeda, M. F.: Characterization of the Region of the Términos Lagoon: Campeche, Mexico, University of Rhode Island, 50 pp., 2004.

Rodríguez-Blanco, A., Antoine, V., Pelletier, E., Delille, D., and Ghiglione, J.-F.: Effects of temperature and fertilization on total vs. active bacterial communities exposed to crude and diesel oil pollution in NW Mediterranean Sea, Environ. Pollut., 158, 663-673, 2010.

Roland, F., Lobão, L. M., Vidal, L. O., Jeppesen, E., Paranhos, R., and Huszar, V. L. M.: Relationships between pelagic bacteria and phytoplankton abundances in contrasting tropical freshwaters, Aquat. Microb. Ecol., 60, 261-272, 2010.

Sauret, C., Böttjer, D., Talarmin, A., Guigue, C., Conan, P., PujoPay, M., and Ghiglione, J.-F.: Top-Down Control of DieselDegrading Prokaryotic Communities, Microb. Ecol., 70, 445458, 2015.

Sauret, C., Tedetti, M., Guigue, C., Dumas, C., Lami, R., Pujo-Pay, M., Conan, P., Goutx, M., and Ghiglione, J.-F.: Influence of PAHs among other coastal environmental variables on total and PAHdegrading bacterial communities, Environ. Sci. Pollut. Res., 23, 4242-4256, 2016.

Scofield, V., Jacques, S. M. S., Guimaraes, J. R. D., and Farjalla, V. F.: Potential changes in bacterial metabolism associated with increased water temperature and nutrient inputs in tropical humic lagoons, Frontiers in Microbiology, 6, doi:10.3389/fmicb.2015.00310, 2015.

Severin, T., Conan, P., Durrieu de Madron, X., Houpert, L., Oliver, M. J., Oriol, L., Caparros, J., Ghiglione, J. F., and Pujo-Pay, M.: Impact of open-ocean convection on nutrients, phytoplankton biomass and activity, Deep-Sea Res. Pt. I, 94, 62-71, 2014.

Sundbäck, K., Miles, A., and Göransson, E.: Nitrogen fluxes, denitrification and the role of microphytobenthos in microtidal shallow-water sediments: an annual study, Mar. Ecol.-Prog. Ser., 200, 59-76, 2000. 
Tedetti, M., Guigue, C., and Goutx, M.: Utilization of a submersible UV fluorometer for monitoring anthropogenic inputs in the Mediterranean coastal waters, Mar. Pollut. Bull., 60, 350$362,2010$.

They, N. H., Ferreira, L. M. H., Marins, L. F., and Abreu, P. C.: Stability of Bacterial Composition and Activity in Different Salinity Waters in the Dynamic Patos Lagoon Estuary: Evidence from a Lagrangian-Like Approach, Microb. Ecol., 66, 551-562, 2013.

Twilley, R. R.: Coupling of Mangroves to the Productivity of Estuarine and Coastal Waters, in: Coastal-Offshore Ecosystem Interactions, Springer-Verlag, 2013.

Tyler, A. C., McGlathery, K. J., and Anderson, I. C.: Benthic algae control sediment - water column fluxes of organic and inorganic nitrogen compounds in a temperate lagoon, Limnol. Oceanogr., 48, 2125-2137, 2003.
Van Wambeke, F., Ghiglione, J.-F., Nedoma, J., Mével, G., and Raimbault, P.: Bottom up effects on bacterioplankton growth and composition during summer-autumn transition in the open NW Mediterranean Sea, Biogeosciences, 6, 705-720, doi:10.5194/bg-6-705-2009, 2009.

Warr, L. N., Friese, A., Schwarz, F., Schauer, F., Portier, R. J., Basirico, L. M., and Olson, G. M.: Bioremediating Oil Spills in Nutrient Poor Ocean Waters Using Fertilized Clay Mineral Flakes: Some Experimental Constraints, Biotechnology Research International, 9, doi:10.1155/2013/704806, 2013.

Weiss, M., Abele, U., Weckesser, J., Welte, W., Schiltz, E., and Schulz, G.: Molecular architecture and electrostatic properties of a bacterial porin, Science, 254, 1627-1630, 1991.

Zimmerman, A. E., Martiny, A. C., and Allison, S. D.: Microdiversity of extracellular enzyme genes among sequenced prokaryotic genomes, ISME J., 7, 1187-1199, 2013. 